\title{
"Eu quero uma casa no campo": a busca do verde em Belo Horizonte, 1966-1976
}

Regina Horta Duarte*

\section{RESUMO}

A expansão de condomínios horizontais esteve diretamente relacionada às condiçóes históricas que acarretaram a deterioração e o abandono do centro urbano de Belo Horizonte, entre meados das décadas de 1960 e 1970 . Nesse contexto, alguns tiveram o privilégio de escolher o sonho da casa no campo, atraídos por promessas de uma vida renovada, mergulhados nos paradoxos do desenvolvimento e dos dramas sociais, políticos e ambientais em curso no Brasil durante a ditadura civil-militar. Cientistas e técnicos realizavam as primeiras avaliaçóes dos dilemas da poluição ambiental urbana. Entretanto, temas ambientais se configuravam como assunto extemporâneo e distante da política, subestimados por setores brasileiros de direita e esquerda. A perda de qualidade de vida em Belo Horizonte recebeu soluções individuais, por vezes com aspectos comunitários. $\mathrm{O}$ caráter simultâneo desses processos na capital mineira esclarece casos históricos similares em outras grandes metrópoles brasileiras e latino-americanas.

Palavras-chave: condomínios privados; Milagre Econômico brasileiro; poluição urbana; Belo Horizonte; história ambiental urbana.

\section{ABSTRACT}

The expansion of private neighborhoods has been directly related to the historical conditions that led to the deterioration and abandonment of the urban center of Belo Horizonte, between the 1960s and 1970s. In this context, some people had the privilege of choosing the country house of their dreams, attracted by promises of a renewed life, immersed in the paradoxes of development and the social/environmental/political dramas taking place in Brazil during the civil-military dictatorship. Scientists and technicians performed then the first evaluations of urban environmental pollution dilemmas. However, environmental issues seemed untimely,

Artigo recebido em 23 de fevereiro de 2014 e aprovado em 15 de abril de 2014.

DOI - http://dx.doi.org/10.1590/2237-101X015028006

* Este artigo resulta de projeto de pós-doutorado desenvolvido junto ao Departamento de História da Unicamp, com apoio do CNPq. Agradecimentos: Viviane S. Parisotto Marino, Yuri Mesquita, Armando Olivetti, Tom, Heloísa Starling e pareceristas anônimos.

** Doutora em história pela Unicamp, professora titular da Universidade Federal de Minas Gerais e bolsista de produtividade científica do CNPq — Nível 1B. Belo Horizonte, MG, Brasil. E-mail: reginahortaduarte@ gmail.com. 
and were a subject far away from politics, underestimated by Brazilian political actors on the Left and on the Right. The decreasing quality of life in Belo Horizonte received individual solutions, sometimes with communal aspects. The simultaneity of these processes in Minas Gerais' capital highlights similar historical circumstances in other Brazilian and Latin American metropolises.

Keywords: private neighborhoods; Brazilian Economic Miracle; urban pollution; Belo Horizonte; urban environmental history.

Eu quero uma casa no campo, Onde eu possa ficar do tamanho da paz. Zé Rodrix, Casa no campo, 1971.

Em 1971, os músicos Zé Rodrix e Tavito ganharam o Festival da Canção de Juiz de Fora com Casa no campo. Como parte do prêmio, participariam ainda da fase nacional do evento, no Rio. Durante um ensaio no Maracanãzinho, Elis Regina se aproximou de Rodrix, segurou seu braço e lhe disse: "eu quero gravar esta canção". Elis já era uma estrela, e Casa no campo estourou nas paradas em 1972. A letra evocava sonhos frugais de uma vida alternativa em meio à natureza, com tranquilidade, simplicidade e paz. Em anos de crescimento desordenado das cidades e caos urbano, com aprofundamento das diferenças entre ricos e pobres, mas também do Milagre Econômico, a repercussão dos versos de Casa no campo certamente foi um entre vários indicadores de um sentimento de mal-estar entre alguns setores da sociedade, gerado pelos graves problemas que a nação então enfrentava. ${ }^{1}$

Outra ressonância cultural da ansiedade que o crescimento urbano desmedido gerou naqueles anos foi o estrondoso sucesso da telenovela Selva de pedra, cuja temática principal explorava alguns dramas das grandes metrópoles brasileiras. A abertura mostrava cenas diversas das ruas de uma metrópole brasileira, com seus arranha-céus, multidôes e o trânsito intenso de veículos. No primeiro plano, o rosto do protagonista se petrificava, sugerindo o endurecimento das pessoas pela vida urbana. ${ }^{2}$

\footnotetext{
${ }^{1}$ Rodrix conta sobre o encontro com Elis em: <www.youtube.com/watch?v=7sVKfQTAwAc>. Sobre os Festivais da Canção e seu sentido político, ver: MELLO, Zuza. A era dos festivais. São Paulo: Ed. 34, 2003. p. 409-411; NAPOLITANO, Marcos. Os festivais da canção como eventos de oposição ao regime militar. In: REIS, Daniel Aarão; RIDENTI, Marcelo; MOTTA, Rodrigo Sá (Org.). O golpe e a ditadura militar. São Paulo: Edusc, 2004. p. 203-216. Em 1970, 55,94\% da população brasileira vivia nas cidades, e o Brasil tinha 93 milhóes de habitantes. Disponível em: <www.ibge.org.br>. Acesso em: 20 dez. 2013.

${ }^{2}$ Sobre a relevância da cultura de massas para a análise da sociedade, ver: ECO, Umberto. Apocalípticos e integrados. São Paulo: Perspectiva, 1990. p. 43-54. Ver também FERREIRA, Mauro. Nossa senhora das oito. Rio de Janeiro: Mauad, 2003. p. 67-74; KEHL, Maria Rita. Novelas, novelinhas e novelóes. In: NOVAIS,
} 
As seçôes imobiliárias dos jornais das grandes cidades brasileiras, na mesma época, exibiam muitos anúncios de novos empreendimentos com lotes para casas de campo em localidades aprazíveis, a alguns minutos de carro do centro urbano, cujo principal atrativo era a proximidade com a natureza. Alguns desses empreendimentos não eram bairros comuns ou subúrbios, mas condomínios privados, alguns com clubes esportivos exclusivos para proprietários e controle da entrada de visitantes. Os proprietários passariam finais de semana e férias nesses autênticos refúgios, longe da turbulência das metrópoles, o que lhes permitiria recarregar forças para sobreviver à selva de pedra de cada dia.

Viver em grandes metrópoles passou a integrar a realidade de um número crescente de pessoas não apenas no Brasil, mas também em outros países da América Latina e do Caribe. Desde o pós-Segunda Guerra Mundial, as cidades latino-americanas — "casulos de modernidade", "arenas culturais" - tornaram-se eixo da transformação econômica e demográfica. ${ }^{3}$ Entre 1950 e 1970, a proporção de citadinos em relação à população total latino-americana saltou de 39 para $54 \%$, o número de cidades com um milhão ou mais de habitantes saltou de oito para dezessete, e a população urbana total latino-americana e caribenha cresceu de aproximadamente 67 para 232 milhôes de habitantes. Num processo de intensa urbanização, muitas cidades latino-americanas foram verdadeiras incubadoras de uma sociedade moderna. Simultaneamente, problemas advindos da concentração urbana vertiginosa expressavam contradiçôes do desenvolvimento desses países, assim como desafios políticos para a conquista de democracia e avanços sociais efetivos. ${ }^{4}$

No caso específico do Brasil, a taxa de urbanização subiu de 31,2 para 55,9\% entre 1940 e 1970. Quando a canção Casa no campo estourava nas paradas de sucesso e a novela Selva de

Adauto. Anos 70, televisão. Rio de Janeiro: Europa, 1979. p. 49-73. A abertura de Selva de pedra está disponível em: <www.youtube.com/watch?v=aKIAzO5Nr_M>. Acesso em: 29 dez. 2013.

${ }^{3}$ MORSE, Richard. Ciudades "periféricas" como arenas culturales. Bifurcaciones, v. 3, p. 1-17, 2005. Disponível em: <www.bifurcaciones.cl>. Acesso em: 12 abr. 2014.

${ }^{4}$ Centro Latinoamericano y Caribeño de Demografía (Celade) - División de Población de la CEPAL. Disponível em: <http://esa.un.org/unup>. Acesso em: 1ำ jan. 2014; GORELIK, Adrian. Das vanguardas a Brasilia. Belo Horizonte: Ed. UFMG, 2005. p. 15-49; GORELIK, Adrian. A produção da "cidade latino-americana". Tempo social, v. 17, n. 1, p. 111-133, 2005; MORSE, Richard. La investigación urbana latinoamericana. Buenos Aires: Siap, 1971. p. 21-22; OLIVEIRA, Orlandina Oliveira; ROBERTS, Bryan. O crescimento urbano e a estrutura urbana na América Latina, 1930-1990. In: BETHEL, Leslie (Ed.). História da América Latina, v. VI: A América Latina após 1930. São Paulo: Edusp, 2005. p. 298-304, 317, 372. Sobre o papel decisivo das cidades na história da América Latina, ver ainda: RAMA, Angel. A cidade letrada. São Paulo: Companhia das Letras, 1985; ARMUS, Diego; LEAR, John. The trajectory of Latin American urban history. Journal of Urban History, v. 24, n. 3, p. 291-301, 1998. Para a história ambiental urbana da América Latina, ver: SEDREZ, Lise. Naturaleza urbana en America Latina, ciudades diversas y narrativas comunes. In: LEAL, Claudia; PÁDUA, José Augusto; SOLURI, John (Ed.). Nuevas historias ambientales de América Latina y el Caribe. Munique: Rachel Carson Center, 2013. p. 59-65; LORETO, Rosalva (Org.). Ciudad y naturaleza: tensiones ambientales en latinoamérica, siglos XVIII-XXI. Puebla: Benemérita Universidad Autónoma de Puebla, 2012. v. 2. 
pedra conquistava os telespectadores, cinco cidades brasileiras possuíam mais de um milhão de habitantes: São Paulo, Rio de Janeiro, Belo Horizonte, Recife e Salvador. ${ }^{5}$

O principal fator do crescimento urbano brasileiro foi o fluxo migratório rural-urbano. Algumas cidades foram cenário de uma verdadeira explosão demográfica. Desde o pós-guerra, o Brasil viveu um crescimento industrial significativo, concentrado predominantemente nas áreas contíguas aos grandes centros, especialmente no Sudeste. As expectativas de emprego e de melhores condiçóes de vida impulsionaram a migração. Entre as diversas consequências desse fenômeno, as questóes ambientais assumiram aspectos de intensa gravidade. Definitivamente as cidades não estavam preparadas para receber um número tão expressivo de habitantes, o que gerou problemas sérios de abastecimento de água, saneamento, alimentos, moradia e transporte, entre outros. A ação das indústrias e fábricas não era limitada por regras de eliminação de resíduos nos rios e solos ou emissão de gases poluentes. Populaçóes pobres se apinhavam nas favelas, onde não havia água potável e os dejetos corriam a céu aberto. Nos bairros, o esgoto era jogado sem tratamento nos cursos de água. A ascensão da classe média levou ao aumento da frota de carros particulares, incrementando a poluição atmosférica nos grandes centros. $\mathrm{O}$ aumento da população e do consumo gerou grandes quantidades de lixo que, na maior parte das vezes, eram incineradas ou levadas para lixôes, pois não havia aterros sanitários. Enfim, as grandes cidades brasileiras começaram a enfrentar uma grave crise ambiental, com problemas de poluição dos rios, solos e atmosfera, além da poluição sonora. ${ }^{6}$

Nada disso ocorreu sem que houvesse também um clima de otimismo e confiança no desenvolvimento, desde a euforia dos anos dourados até o ufanismo da década de 1970. Mas argumentarei que a rapidez e a profundidade dessas mudanças criaram uma espécie de mal-estar da civilizaçáo, um sentimento latente de que, para se ganhar o que o desenvolvimentismo prometia, e parcialmente entregava, havia também um preço alto a ser pago, com perdas expressivas e renúncia a alguns elementos da felicidade. Entre esses, o contato com a "natureza", ou o que se idealizava como tal, foi uma das privaçôes lamentadas e que alguns habitantes procuraram compensar, na medida de suas possibilidades.

\footnotetext{
${ }_{5}^{5}$ Disponível em: <http://seculoxx.ibge.gov.br>. Acesso em: 1o jan. 2014. Em 8 de junho de 1973, a Lei Complementar 14 criou as regióes metropolitanas no Brasil (Sáo Paulo, Belo Horizonte, Porto Alegre, Recife, Salvador, Curitiba, Belém e Fortaleza).

${ }^{6}$ Entre 1950 e 1979, 30 milhóes de pessoas migraram do campo para as cidades no Brasil. MELLO, João Manuel C.; NOVAIS, Fernando. Capitalismo tardio e sociabilidade moderna. In: SCHWARCZ, Lilia M. (Org.). História da vida privada, v. 4. São Paulo: Companhia das Letras, 2004. p. 581; BRITO, Fausto. O deslocamento da população brasileira para as metrópoles. Estudos Avançados, v. 20, n. 57, p. 221-236, 2006. Historiadores têm desenvolvido estudos pioneiros sobre história ambiental urbana de grandes cidades brasileiras: SEDREZ, Lise. "The Bay of all Beauties": State and environment in Guanabara Bay, Rio de Janeiro, Brazil, 1875-1975. Dissertation (PhD in history) — Department of History, Stanford University, Stanford (Cal.), 2004; JORGE, Janes. Tietê, o rio que a cidade perdeu. São Paulo: Alameda, 2007. Para a ideia de crise ambiental urbana, ver: MELOSI, Martin V. Environmental crisis in the city. In: MELOSI, Martin V. Pollution and reform in American Cities. Austin: University of Texas Press, 1980. p. 3-31.
} 
Entre as várias cidades brasileiras que apresentaram crescimento demográfico, industrialização e aprofundamento de problemas ambientais, este artigo privilegiará a capital de Minas Gerais, Belo Horizonte. Essa escolha tem razões. No início de sua história, Belo Horizonte apareceu como localidade onde o urbano e os elementos naturais se harmonizavam. Essa capital, projetada em fins do século XIX, foi cantada em prosa e verso, nas suas primeiras décadas de existência, por sua arborizaçáo exuberante. As justificativas de escolha do local para a nova capital alardearam a abundância e a pureza das águas de seus córregos e do ribeirão Arrudas para o abastecimento dos habitantes. A fama do poder curativo de seus ares benfazejos espalhou-se por todo o Brasil, e mesmo em alguns centros médicos na Europa, tornando-a destino de esperança para os enfermos com tuberculose. O sossego cotidiano e a vida pacata eram tấo marcantes que provavelmente entediaram Noel Rosa, que chegou ali em 1935, aconselhado por seu médico, para se tratar de tuberculose, mas concluiu preferir um ano apenas de vida no Rio de Janeiro a dez em Belo Horizonte. ${ }^{7}$

Belo Horizonte viveu mudanças profundas no pós-guerra, o que levou alguns autores a considerá-la quase uma caricatura do desenvolvimento capitalista na América Latina, com impressionante processo de industrialização sem inovação tecnológica, modernização em paralelo com aprofundamento selvagem das desigualdades e do patrimonialismo e submissão ao capital internacional. Entre 1950 e 1970, a migração foi responsável por 58\% do crescimento da capital, cuja população saltou de 352.723 para 1.235 .030 habitantes. A malha urbana expandiu-se consideravelmente (figura 1). No centro, houve dinamização dos setores comerciais e de serviços, e os arranha-céus ganharam destaque nas paisagens de Belo Horizonte. Paralelamente aos bolsóes de pobreza extrema, ascenderam os setores de classes médias e fortaleceram-se as elites empresariais, cuja projeção aumentou no cenário político nacional. ${ }^{8}$ Já em meados dos anos 1960, pesquisas em jornais, entrevistas, relatórios de prefeitos, estudos de engenharia sanitária e de saúde pública mostram uma cidade transformada, com diminuiçáo radical da arborização para o alargamento das

\footnotetext{
${ }^{7}$ Ver MIRANDA, Wander Melo (Org.). Belo Horizonte, a cidade escrita. Belo Horizonte: Ed. UFMG, 1996 (especialmente o "Noturno de Belo Horizonte", 1924, de Mário de Andrade, p. 75-89). Sobre a avaliação positiva da região pela Comissão Construtora: REIS, Aarão. Commissão Constructora da Nova Capital. Revista geral dos trabalhos. Rio de Janeiro: H. Lombaerts e Cia, 1895. v. 1, p. 21; VIANNA, Newton. Belo Horizonte, seu abastecimento de água e sistema de esgotos, 1890-1973. Belo Horizonte: EEUFMG, 1997. p. 31. Um caráter salutar excepcional era atribuído ao clima de Belo Horizonte: LABOISSIÈRE, Márcia. Imagens do mal: a tuberculose em cinquenta anos da história de Belo Horizonte. Dissertação (mestrado em história) - Programa de Pós-Graduação em História, Universidade de Campinas, Campinas, 1998. p. 63-78. MARTINS, Fábio. 1935: Noel Rosa em Belo Horizonte. Rádio em Revista, v. 4, n. 1 e 2, p. 10-15, 2008.

${ }^{8}$ Os dados demográficos referem-se apenas ao município de Belo Horizonte, com $331 \mathrm{~km}^{2}$, e encontram-se em PLAMBEL. O desenvolvimento econômico e social da regiáo metropolitana de BH. v. III. Belo Horizonte: SPMG, 1974. p. 3-5. Para análises do desenvolvimento capitalista em Minas e a importância da área industrial da grande Belo Horizonte que, em 1973, abrangia quatorze municípios, num território de $3.669 \mathrm{~km}^{2}$, ver DINIZ, Clelio Campolina. Estado e capital estrangeiro na industrialização mineira. Belo Horizonte: UFMG/ Proed, 1981. p. 21; EAKIN, Thomas. Tropical capitalism. Nova York: Palgrave, 2001. p. 7, 172-179.
} 
ruas, córregos poluídos e fétidos, acúmulo de lixo, enchentes, engarrafamentos, poluição do ar e sonora.

\section{Figura 1}

Expansão da malha urbana do município de Belo Horizonte e área central da Região Metropolitana de Belo Horizonte

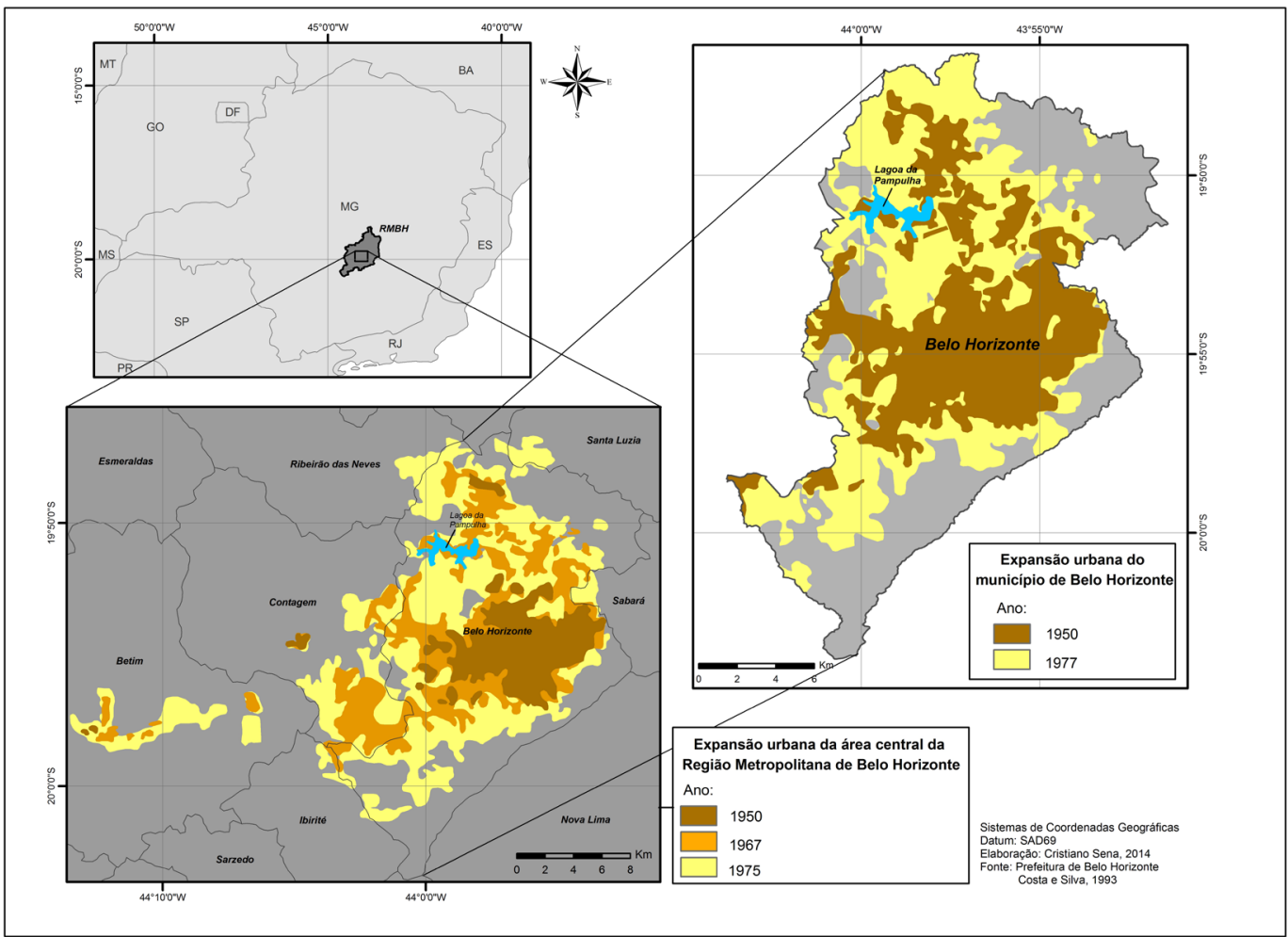

Fontes: Prefeitura de Belo Horizonte; COSTA, Sandra Maria Fonseca da. Urbanização da Região Metropolitana de Belo Horizonte: monitoramento do crescimento urbano através do monitoramento de informaçóes geográficas pelo sistema SGI/Inpe. In: SIMPÓSIO BRASILEIRO DE SENSORIAMENTO REMOTO, VII, 1993, Curitiba. Anais... Curitiba: SBSR, 1993. p. 41-47. Elaboração: Cristiano Sena, 2014.

Nesse contexto, Belo Horizonte conheceu muito precocemente o fenômeno dos condomínios privativos em seu entorno, especialmente no setor sul, grande parte deles para casas de finais de semana, voltados para o público de classe média e alta, numa busca privilegiada da compensaçáo das perdas da vida na metrópole. ${ }^{9}$ Alguns empreendimentos surgiram em

\footnotetext{
${ }^{9}$ É importante destacar que tal fenômeno integra a história de outras cidades da América Latina, e Belo Horizonte participa de uma tendência urbana muito mais ampla. Para estudos da expansão de condomínios em cidades como São Paulo, Buenos Aires, Santiago do Chile e Lima, ver: CALDEIRA, Teresa. Cidade de muros. Sáo Paulo: Ed. 34; Edusp, 2000; SVAMPA, Maristella. Los que ganáron. 2. ed. Buenos Aires: Biblios, 2008; COY, Martin. Gated communities and urban fragmentation in Latin America. Geojournal, v. 66, n. 1, p. 121-132, 2006; JANOSCHKA, Michael. El nuevo modelo de la ciudad latino-americana. Eure, v. 28, n. 85, p. 11-20, 2002; DAM, Paulo. La ocupación del desierto de la playa Asia, Lima Peru. $A R Q$, v. 57, n. 1, p. $56-$
} 
fins dos anos 1950, mas a avidez pelas últimas áreas verdes, com ar puro, silêncio e nascentes cristalinas, incrementou o número de lançamentos nos anos 1970. O presente artigo analisará tal movimento em direção a refúgios verdes, realizado por alguns habitantes de Belo Horizonte, num contexto da urbanização desenfreada entre 1966 e 1976. A busca da "casa de campo" foi privilégio de membros das classes médias mais abastadas, que certamente se beneficiavam do crescimento econômico vivido pelo Brasil nos anos do Milagre Econômico mas que, paradoxalmente, lamentavam a perda da qualidade de vida no centro urbano.

O ano de 1966 aparece como momento-chave para a análise. Paralelamente às promessas desenvolvimentistas, aquele ano trouxe sinais importantes do endurecimento do regime político autoritário vigente desde o golpe civil-militar de 1964. Por outro lado, o Programa de Ação Econômica do Governo demonstrou seus primeiros resultados, e o Produto Interno Bruto (PIB) deu mostras de recuperação, num processo que pouco depois instaurou um período de grande prosperidade para as classes médias e as elites. Em Belo Horizonte, o prefeito nomeado iniciou um projeto de remodelamento urbano ambicioso, o Nova $\mathrm{BH}$ 66. Nessas condiçóes históricas - entre o caos urbano, o estreitamento da esfera política de açáo, as açóes de luta contra a ditadura e a euforia econômica — os loteamentos para casas de finais de semana ganhariam novo impulso.

Em 1976, os problemas da cidade eram ainda mais graves, e as fragilidades do regime político em vigor começavam a ser expostas pela crise econômica. Carlos Drummond de Andrade, cuja poesia se dedicou tantas vezes aos encantos da cidade de outrora, publicou "Triste horizonte". Nesses versos, Drummond lamentava as perdas sofridas e ansiava esquecer a "brutal Belo Horizonte que se empavonava sobre o corpo crucificado da primeira". ${ }^{10}$ A despeito do enfraquecimento da construção civil, os condomínios privados continuaram crescendo, tornando-se cada vez mais um local de moradias permanentes, numa fuga agora motivada sobretudo pela insegurança, em meio à escalada da violência urbana.

Entre 1966 e 1976, Belo Horizonte compartilhou paradoxos comuns a outras grandes cidades latino-americanas: crescimento econômico/aprofundamento da pobreza, ufanismo/ desencanto, aumento do consumo e do nível de vida das classes médias/falta de saneamento básico e altas taxas de mortalidade infantil, otimismo/mal-estar. Nesses tempos táo paradoxais, os sentidos latentes no sonho idílico da casa de campo, realizável para uma pequena parcela de privilegiados em meio aos intrincados problemas da terceira metrópole brasileira, apresentam-se como um campo instigante de análise, com implicaçóes para a história política, social e ambiental urbana do período em questão. 


\section{Selva de pedra}

O projeto Nova BH 66 prometeu a solução dos problemas gravíssimos que se acumulavam na capital. Acenou com a regularização do abastecimento de água potável, a canalização dos córregos como solução para sua poluição, amplos trabalhos de pavimentação e asfaltamento de vias, melhoria do transporte público. O projeto se apoiou sobretudo no rodoviarismo - estimulando usinas de asfaltos e alimentando a indústria automobilística - e o carro particular foi consagrado como protagonista privilegiado das ruas. Como sinal do privilégio do carro particular em detrimento do pedestre, os números alardeados pelo relatório da prefeitura são significativos: em 1966, asfaltou-se um milhão de metros quadrados de vias, num gasto total de 5,5 milhóes de cruzeiros. No mesmo ano, apenas 3 mil metros quadrados de passeios para pedestres foram construídos, com custo de 20 mil cruzeiros, além de 10 mil cruzeiros para a manutenção de $1.500 \mathrm{~m}^{2}$ de passeios. ${ }^{11}$

A cidade se tornou um verdadeiro canteiro de obras, causando grandes transtornos cotidianos. A prefeitura investiu na publicidade, visando conquistar a paciência da população e estimular a confiança no progresso. Uma das propagandas apresentava o sr. D.B., a única pessoa que estaria insatisfeita. $\mathrm{O}$ abaixo-assinado que organizara contra a prefeitura continha apenas a sua assinatura. Com "a opinião formada sobre uma porção de coisas”, o personagem aparecia caracterizado com suspensórios, óculos pince-nez, gravata ridícula, costeletas, bigode e cabelo antiquados. No pano de fundo, avista-se a cidade com seus edifícios. O céu azul contrasta com o guarda-chuva que o sr. D.B. traz nas mãos. Ele tinha opinióes absurdas sobre a seleção brasileira, achava Ursula Andress feia, defendia que Belo Horizonte estava inabitável, barulhenta e empoeirada com tantas obras. O cheiro de asfalto e a fumaça do número crescente dos ônibus a diesel o deixavam nauseado (figura 2). Dias depois, outra publicidade trazia o pedido de desculpas da prefeitura pela poeira e incômodos, mas pedia às mães que compreendessem por que as roupas das crianças se sujavam tão mais depressa. Em breve, Belo Horizonte seria uma cidade moderna e mais bela, com ruas asfaltadas e córregos escondidos. Na foto, uma turma de operários trabalha na rua, tendo ao fundo a linha do horizonte da serra do Curral. Para uma cidade que sofria terrivelmente com a falta de água, a prefeitura anunciava ainda que conseguira 12 milhóes de dólares para captar água do rio das Velhas, e que "a lata d'água na cabeça de Maria” seria, em breve, apenas a letra de um samba. Além de matérias pagas em jornais, um encarte foi veiculado no final do ano, com

\footnotetext{
${ }^{11}$ PREFEITURA de Belo Horizonte. Relatório do Exercício de 1966. Belo Horizonte: PBH, jan. 1967. p. 132-133. Sobre as canalizações de córregos empreendidas pelo Nova BH 66 e o predomínio do asfalto, ver MESQUITA, Yuri. Jardim de asfalto: água, meio ambiente, canalização e as políticas públicas de saneamento básico em Belo Horizonte, 1948-1973. Dissertação (mestrado em história) — Programa de Pós-Graduação em História, Universidade Federal de Minas Gerais, Belo Horizonte, 2013. p. 138-142.
} 
lindas vistas da cidade, suas ruas asfaltadas, circulação de ônibus a diesel nas ruas, e imagens das obras ainda em curso e que dinamizariam a vida urbana, comemorando "o cheiro de asfalto quente [que] invadiu toda a cidade" (figura 3 ). ${ }^{12}$

\section{Figura 2}

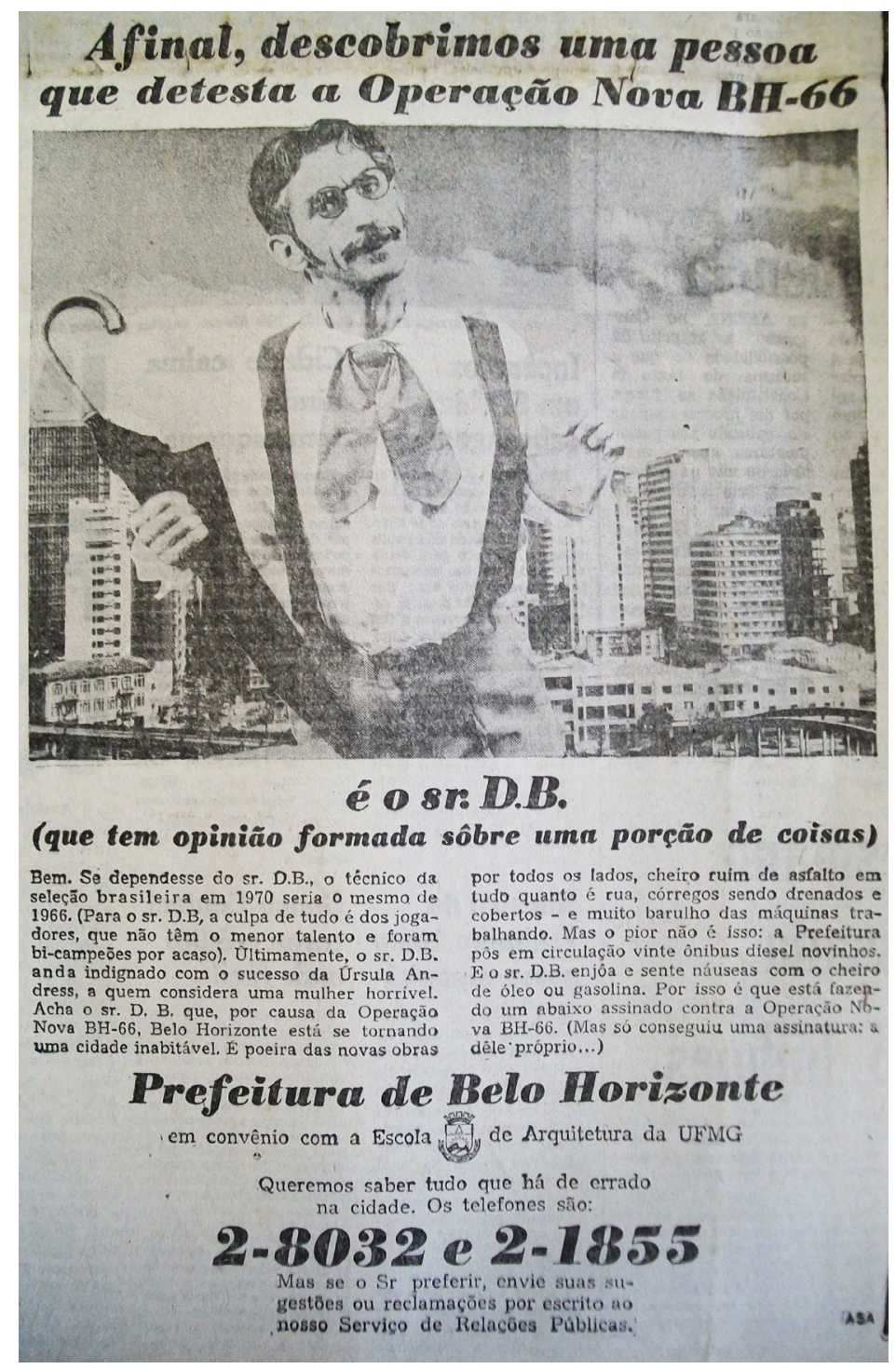

Fonte: Diário de Minas, Belo Horizonte, 31 jul. 1966. p. 2

(Hemeroteca Histórica do Estado de Minas Gerais).

${ }^{12}$ As matérias publicitárias encontram-se em: Estado de Minas, Belo Horizonte, 20 jun. 1966. p. 7; Estado de Minas, 17 jul. 1966. p. 2; Diário de Minas, Belo Horizonte, 31 jul. 1966. p. 2. Note-se que Ursula Andress estava no auge de sua glória, desde sua cena de biquíni branco em Dr. No (1962). O folheto Nova BH 66 foi encarte do jornal Diário de Minas em 11/12 dez. 1966 (Hemeroteca Pública de MG). Yuri Mesquita me indicou generosamente a referência do Sr. D.B. 
Figura 3

Nova BH 66

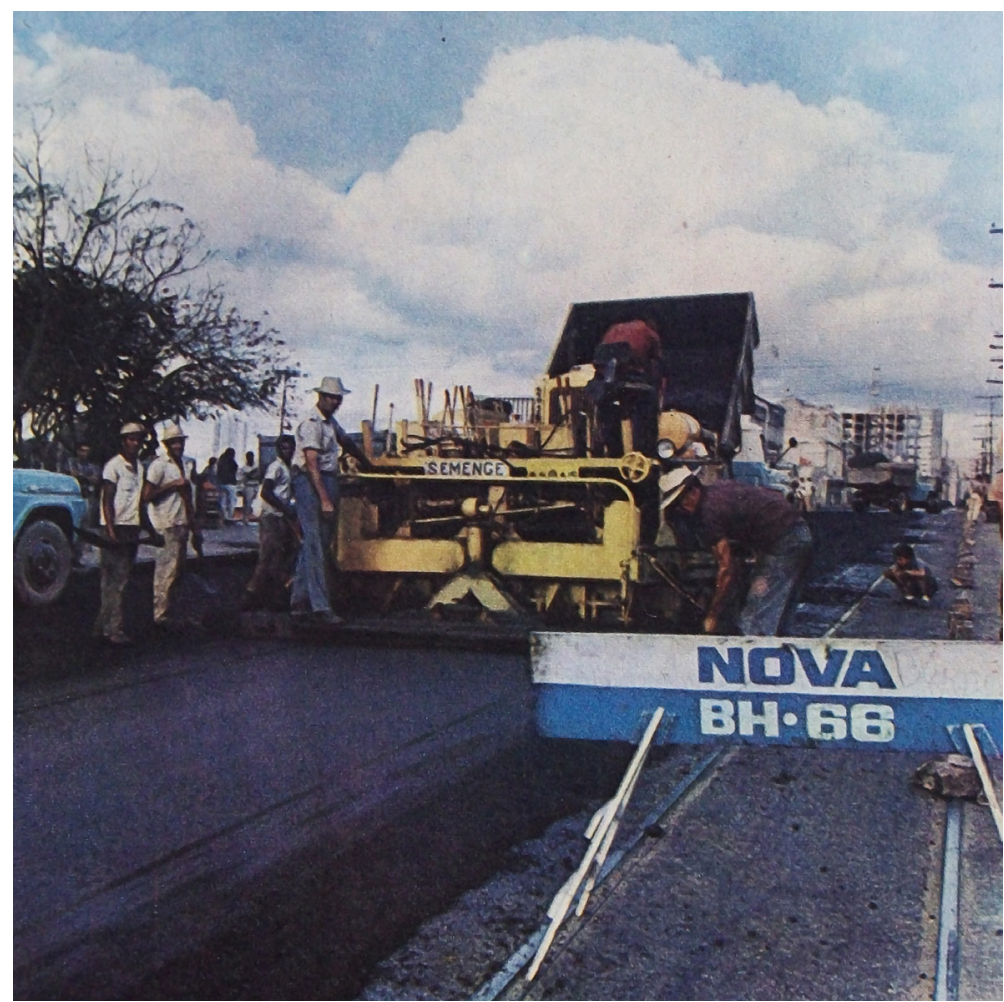

Fonte: Encarte do Diário de Minas, 11/12 dez. 1966

(Hemeroteca Histórica do Estado de Minas Gerais).

Nos anos seguintes, altas taxas de crescimento econômico do PIB (acima de 11,2\% ao ano entre 1968 e 1973, alcançando 14\% em 1974) catapultaram o poder de consumo das camadas médias, e o carro particular certamente foi um dos bens mais imediatamente desejados, com todos os signos de prestígio que o cercavam (figura 4). O aumento da frota de veículos em Belo Horizonte representou um fator importante no processo de grande deterioração ambiental do centro da cidade que, até o final dos anos 1960, possuía muitos prédios residenciais com bons apartamentos ocupados por famílias de classe média e alta. O centro concentrava ainda escritórios de advocacia, consultórios médicos e odontológicos, companhias de aviação e agências de turismo, hotéis, bons restaurantes, lojas de roupas finas, empresas jornalísticas, livrarias, cafés, agências bancárias, escolas de línguas e consulados, e tudo isso gerava um grande movimento. Numa área central de ruas quadriculadas e avenidas em diagonal, um verdadeiro caos se instalou com a circulaçáo crescente de veículos sem planejamento adequado de semáforos, deficiência de passagens adequadas para pedestres e a prática de estacionar veículos particulares indiscriminadamente pelas ruas, canteiros centrais e até nos passeios. Tudo isso gerou situaçóes de grande morosidade, estrangulamen- 
to de vias, poluição sonora causada não apenas pela característica ruidosa dos motores da época, mas também pelas buzinas de motoristas impacientes. Em abril de 1972, o professor Oromar Moreira, da Faculdade de Medicina da Universidade Federal de Minas Gerais (UFMG), saiu às ruas do centro com um aparelho medidor de ruídos e constatou a média de 68 decibéis. Em algumas vias, entretanto, o nível chegava a 90 decibéis em horários de pico, quando o tolerável para a saúde humana seriam até 40 decibéis. Em 1975, iniciativa similar realizada pelo médico Thelmo Quick mostrou que a média das áreas centrais aumentara, e os níveis nas ruas centrais chegavam a até 104 decibéis. ${ }^{13}$

\section{Figura 4}

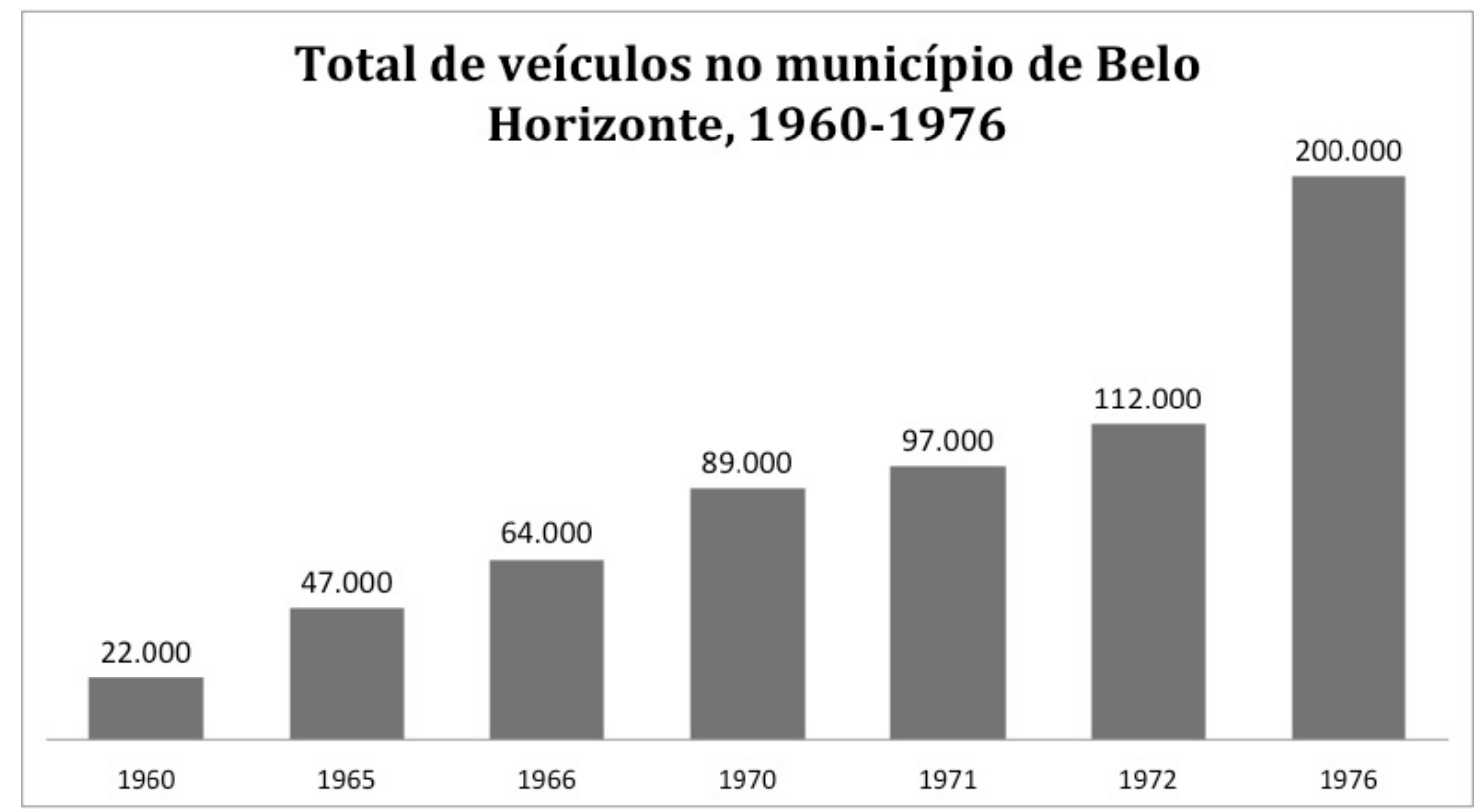

Fonte: PLAMBEL. Estudo do sistema de órgãos encarregados do transporteltrânsito, 1974. p. 20. Arquivo Público da Cidade de Belo Horizonte. Fundo: Secretaria Municipal de Planejamento. AH 06/00/00 - GR 520. Arranjo TX/EP.40/PT.02/CX 96. Dados de 1976: AUMENTO de carros preocupa prefeito de Belo Horizonte. Estado de Minas, 26 jun. 1976. p. 5. Elaboração: Regina Horta Duarte.

\footnotetext{
${ }^{13}$ Sobre milagre econômico, consumo e comércio, ver: GOMES, Angela de C. Economia e trabalho no Brasil republicano. In: GOMES, Angela de C.; PANDOLFI, Dulce; ALBERTI, Verena (Org.). A República no Brasil. Rio de Janeiro: Nova Fronteira; FGV, 2001. p. 253-257; ALBERTI, Verena. O século do moderno: modos de vida e consumo na república. In: GOMES, Angela de C.; PANDOLFI, Dulce; ALBERTI, Verena (Org.). A República no Brasil, op. cit. p. 301-338. Sobre o centro de BH, ver: BELO Horizonte. Revista Minas Gerais, n. 1, p. 105, 1961; FUNDAÇÃO JOÃO PINHEIRO. Belo Horizonte e comércio: 100 anos de história. Belo Horizonte: FJP, 1997. p. 115-158. Sobre a relação de brasileiros com seus carros e os sentidos simbólicos envolvidos, ver WOLFE, Joel. Autos and progress: the Brazilian search for modernity. Nova York: Oxford University Press, 2010. Sobre a iniciativa do drs. Moreira e Quick ver, respectivamente: O SOM e a fúria moram com você nas ruas da cidade. Estado de Minas, 16 abr. 1972. p. 5; FIRMINO. Hiram. Esse barulho ainda vai nos deixar todos surdos. Estado de Minas, 15 jun. 1975. p. 13.
} 
A poluição atmosférica também se tornou um problema crescentemente sério, deixando no passado a imagem dos ares de Belo Horizonte como refúgio restaurador para os acometidos por doenças pulmonares. O transporte público elétrico antes existente na cidade foi gradativamente substituído por ônibus a diesel e completamente extinto em 1969. A gasolina e o diesel então comercializados emitiam grandes concentrações de enxofre e chumbo. O desenho quadriculado das ruas do centro urbano favorecia morosidade mesmo fora dos horários de rush, pois tantos cruzamentos exigiam paradas e arrancos constantes. A moda do carro "envenenado" levava muitos motoristas a realizarem alteraçôes nos motores para aumentar a potência, incorrendo em maior gasto de combustível e aumento do ruído. Os modelos de carros tinham um desempenho fraco em termos de consumo por quilômetro rodado. Enfim, a cultura do carro disseminava-se em condiçóes fortemente poluidoras. ${ }^{14}$

Desde fins dos anos 1960, o tema da poluiçáo do ar ganhou as manchetes dos jornais locais, estudos médicos e de engenharia sanitária, promessas da prefeitura e de seus órgãos de controle urbano, assim como a atençáo da população, para quem seus efeitos deletérios se tornaram crescentemente perceptíveis. Em Belo Horizonte, todos os discursos sobre poluição do ar foram unânimes em distinguir a poluição no centro da cidade (causada pelo tráfego de veículos) da poluiçâo de origem industrial. Esta última se concentrava na Cidade Industrial, mas vários bairros belo-horizontinos de classes médias baixas e pessoas em condiçóes de pobreza sofreram com a vizinhança de fábricas diversas, usinas de asfalto e outras. O crescimento significativo da taxa de mortalidade na capital, por bronquite, asma e enfisema pulmonar, naquele período, é um dos indícios da piora da qualidade do ar (figura 5).

\footnotetext{
${ }^{14}$ O chumbo melhorava o desempenho do veículo e era adicionado desde os anos 1920. Começou a ser eliminado da gasolina em 1989, no Brasil (e, completamente, em 1992): A Petrobras apresenta a primeira manifestaçấo ecológica do ano, a gasolina totalmente sem chumbo. 1989. Disponível em: <http://memoria. petrobras.com.br/acervo/chumbo-tetraelita-e-retirado-da-gasolina\#.U2Lg0sbNDn0>. Acesso em: 31 out. 2013. Ver ainda: LANDRINGAN, Phillip. The worldwide problem of lead in petrol. Bulletin of the World Health Organization, v. 80, n. 10, p. 768, 2002; MINISTÉRIO DO MEIO AMBIENTE. Primeiro inventário nacional de emissão de veículos automotores rodoviários. Brasília: Ministério do Meio Ambiente, 2011; MARAZZI, Expedito. Seu corcel vai render mais com veneno. Quatro Rodas, São Paulo, ano XI, n. 129, p. 91-95, abr. 1971; VICENTINO, Flávio; MANERA, Roberto. Escolha o veneno para seu Chevette. Quatro Rodas, ano XV, n. 169, p. 86-91, ago. 1974. Disponível em: <http:/quatrorodas.abril.com.br/acervodigital/ home.aspx>. Acesso em: 17 jan. 2014; I SIMPÓSIO SOBRE TRÂNSITO DE BH. Belo Horizonte: Câmara de Deputados, 1975. 3 v.
} 


\section{Figura 5}

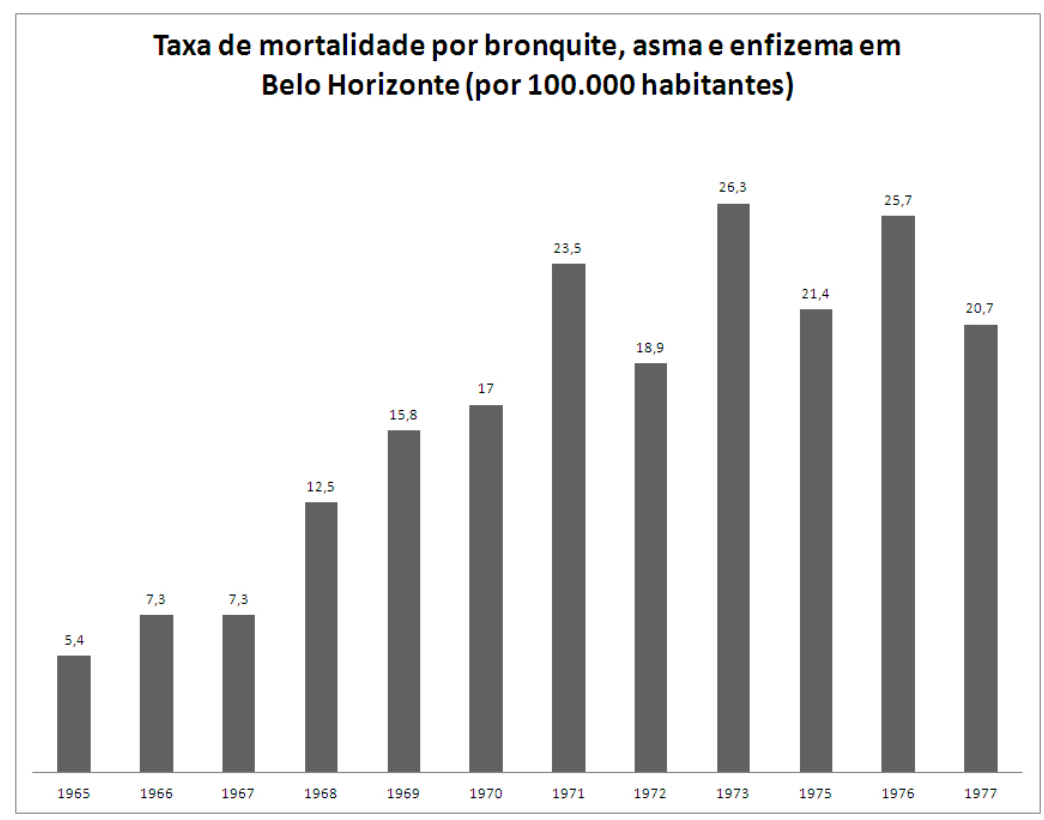

Fonte: IBGE, Estatísticas do século XX: saúde. Disponível em: <www.ibge.org>. Elaboração: Regina Horta Duarte.

Em 1968, um professor de engenharia sanitária da UFMG, Honório Pereira Botelho, denunciou o aumento de doenças alérgicas em decorrência da poluição na cidade. Por meio de convênio dessa Universidade com a Organização Pan-Americana de Saúde (Opas), Belo Horizonte instalaria sua primeira estação de controle de poluição do ar em dezembro de $1971 . .^{15}$

A inauguração da estação medidora possibilitou a realizaçáo de estudos fundamentados sobre os níveis de poluição em Belo Horizonte. Em 1972, o médico Thelmo Quick e o engenheiro químico Ernest Paulini realizaram um estudo sobre os níveis de emissão de vários agentes poluentes no centro e nas áreas industriais de Belo Horizonte. Os dois trabalharam com medidores móveis em vários pontos da cidade. Além da gravidade extrema das áreas industriais (especialmente nas imediaçôes de fábricas de cimento, com destaque para a Itaú, e para a siderúrgica Mannesmann, no Barreiro, que funcionavam sem filtros ou controle de

${ }^{15}$ BOTELHO, Honório Pereira. Ar poluído provoca surto de doenças alérgicas na cidade. Estado de Minas, 29 out. 1968. p. 15; Id. Poluição do ar. Belo Horizonte: 1969. Mimeografado. (Acervo Memória, Escola de Engenharia da UFMG); BOTELHO, Honório Pereira. Contribuição ao estudo da poluição industrial em Minas Gerais. Dissertação (mestrado em engenharia sanitária) - Programa de Pós-Graduação em Engenharia Sanitária, Universidade Federal de Minas Gerais, Belo Horizonte, 1980. Sobre a presença da Opas em Belo Horizonte para controle da poluição: Depoimento concedido por Jesus Miguel Tajra Adad, 26 nov. 2013. Na época, o prof. Adad dirigiu o Laboratório de Controle de Poluição do Ar, situado na Escola de Engenharia da UFMG, no centro da cidade. 
resíduos), alguns pontos do centro eram críticos. No túnel Concórdia-Lagoinha, obra inaugurada com pompa e circunstância pela prefeitura em 1969, os gases eram táo concentrados que, na situação hipotética de um acidente que causasse um engarrafamento de vinte minutos, o monóxido de carbono (CO) atingiria um nível letal para os ocupantes dos veículos. Muitas pessoas sentiam náuseas ao percorrer o túnel, especialmente nas horas mais movimentadas. Outras áreas centrais apresentavam níveis de poluentes acima do limite aceitável para a saúde humana, com danos diretamente proporcionais ao tempo de permanência no local. O diesel a a gasolina também emitiam aldeídos, hidrocarbonetos, óxidos de nitrogênio e partículas sólidas. A estação não possuía aparelhos adequados para todas as mediçôes, mas apontava a diminuição da visibilidade e uma nítida sensação de desconforto entre os transeuntes para argumentar que a poluição já era um problema significativo para os belo-horizontinos. Dados técnicos de 1976 indicaram algumas substâncias poluentes com níveis cinquenta vezes acima do máximo recomendado pela Organização Mundial de Saúde (OMS). ${ }^{16}$

Além dos carros, outros problemas pioravam a qualidade do ar, como a prática de incineração de lixo (apenas 46\% do lixo produzido pelo município era coletado) e a grande frequência de queimadas nos limites da cidade. Nos períodos de estio, havia episódios do envolvimento de toda a cidade por uma bruma que chegava a interferir na visibilidade do aeroporto. Os primeiros episódios de inversão térmica se faziam visíveis e se tornariam cada vez mais frequentes na estação seca. O horizonte, belo e azul na memória recente dos moradores, em poucos anos mesclou-se à cor da fuligem. ${ }^{17}$

O clima ameno da cidade também sofreu alteraçóes de forma bastante perceptível aos habitantes. Para isso, contribuíram tanto a pavimentação das ruas e a canalização dos córregos, como a diminuição notória da arborização da cidade. Ao longo da história de Belo Horizonte, o Parque Municipal localizado no centro teve sua área inicial reduzida de 550 mil para 180 mil metros quadrados. Desde o início dos anos 1960, o alargamento das vias rodoviárias urbanas determinava a eliminação de canteiros e árvores. Souza Lima, prefeito entre 1967 e 1971, era ridicularizado pela fúria com que árvores eram derrubadas durante seu mandato: charges de

\footnotetext{
${ }^{16}$ QUICK, Thelmo; PAULINI, Ernest. Contribuição ao estudo da poluição atmosférica e das doenças pulmonares em Belo Horizonte. Belo Horizonte: Academia Mineira de Medicina, 1973. p. 9-18. Ver ainda PAULINI, E. Crise ambiental. Belo Horizonte: Crea/EEUFMG, 1974; PLAMBEL. Poluição atmosférica na Região Metropolitana de Belo Horizonte. Belo Horizonte: FJP, 1973; G Mimeografado; GOVERNO DO ESTADO DE MINAS GERAIS. Situação ambiental na Região Metropolitana de Belo Horizonte. Belo Horizonte: s.n., 1976. p. 64-68.

${ }^{17}$ A incineração de lixo pelos habitantes era permitida por lei, desde que realizada durante o dia. Lei Municipal 1.479, 26 abr. 1968. Sobre a fumaça escura que saía dos prédios pela queima de lixo, ver: NOTAS do dia: lixo. Estado de Minas, 21 dez. 1974. p. 5. A poluição se tornava crescentemente visível no inverno: NÉVOA seca. Diário de Minas, Belo Horizonte, 4 ago. 1966. p. 5; NO ar, nosso veneno de cada dia. Estado de Minas, 14 set. 1975. p. 20; BELO Horizonte é tomada pela poluição. Estado de Minas, 18 jun. 1976. p. 5; A MAIS forte inversão térmica deste ano foi ontem pela manhã. Estado de Minas, 15 jul. 1977. p. 5. Fotos de episódios de inversão podem ser encontradas em: GOVERNO DO ESTADO DE MINAS GERAIS. Situação ambiental na Regiáo Metropolitana de Belo Horizonte, op. cit. p. 55-56, 64.
} 
jornais o mostravam com um machado nas mãos, com expressóes de avidez dendroclasta. Cientistas e intelectuais organizaram moções de protesto contra a supressão de árvores. Espaços de lazer público eram exíguos e, em 1976, havia minguados 0,7 $\mathrm{m}^{2}$ de área verde por habitante em Belo Horizonte, quando a OMS já estipulava o mínimo de $12 \mathrm{~m}^{2} .^{18}$

Nos bairros de população pobre, a falta de regulamentação urbana e fiscalização abria o caminho para a instalação de pequenas fábricas, a exemplo de usinas de asfalto de menor porte, mas que causavam grande poluição pela falta de filtros, pelo ruído e pelo livre descarte de resíduos. Os moradores do Barreiro, especialmente, amargaram a grave poluição causada pela Siderúrgica Mannesmann, e o hospital regional vivia abarrotado de crianças e adultos com graves crises respiratórias. Houve muitos casos de organização de comunidades em torno de açóes legais populares contra usinas de concreto ou asfalto, fábricas de lubrificantes, de cigarros e fundiçốes, entre outras. A despeito das ações e denúncias, os estabelecimentos permaneceram por anos a fio sem qualquer regulamentação e sem filtros. ${ }^{19}$

Em algumas ruas do centro da cidade, prédios de apartamentos amplos e espaçosos eram, até então, habitados por pessoas de classes médias mais favorecidas. Mas a poluição, o barulho e a mendicância pelas ruas as tornaram gradativamente inadequadas aos olhos de pessoas de melhor condição social. Outro fator de insatisfação era a inexistência de garagens em prédios antigos. Tudo isso levou ao abandono do centro como local desejável para moradia, num processo de crescente deterioração. ${ }^{20}$

A Pampulha, projetada nos anos 1940 como bairro privilegiado para mansóes e lazer de elites, com a construção de uma lagoa cercada de obras-primas da arquitetura e do paisagis-

\footnotetext{
${ }^{18}$ Os dados sobre áreas verdes e coleta de lixo são do relatório GOVERNO DO ESTADO DE MINAS GERAIS. Situação ambiental na Regiāo Metropolitana de Belo Horizonte, op. cit. p. 18, 30, 48. Ver ainda: BELO Horizonte, uma cidade sem verde e sem áreas de lazer. Estado de Minas, 19 out. 1975. p. 11; CIDADE ganha em calor o que perdeu no corte de árvores no centro. Estado de Minas, 1o jan. 1971. Sobre o Parque Municipal de Belo Horizonte nos anos 1960 e 1970, ver: COMPANHIA Vale do Rio Doce. Parque Municipal: crônica de um século. Belo Horizonte, 1992. p. 99-111. Um exemplo de charge sobre o corte de árvores pela prefeitura: ESTEVES, Oldack. Imagens do dia (charge). Estado de Minas, 10 dez. 1970. p. 4. Sobre os protestos da comunidade acadêmica: CIENTISTAS condenam corte de árvore e levam o seu manifesto a Souza Lima. Estado de Minas, 1ำ nov. 1968. p. 5; TÉCNICO em botânica diz que corte de árvores em BH é crime contra o povo. Estado de Minas, 27 out. 1968. p. 5.

${ }^{19}$ As chaminés da Siderúrgica Mannesmann expeliam fumaça vermelha e densa, altamente tóxica, e os filtros só foram instalados em 1978: AFINAL acabou a poluição da Mannesmann. Estado de Minas, 16 mar. 1978. p. 5. Para outros exemplos em diferentes bairros populares: UM plano contra a poluição. Estado de Minas, 26 abr. 1970. p. 6; POLUIÇÃO: a fumaça venceu. Estado de Minas, 27 jul. 1972. p. 5; NA Lagoinha há nuvens de cimento. Estado de Minas, 11 out. 1973. p. 7; SEGUNDO o que se diz, poluição do óleo continuará. Estado de Minas, 14 set. 1974. p. 7; QUEREM que a fábrica pare com poluição. Estado de Minas, 14 jan. 1975. p. 5; ESTA fábrica vai continuar poluindo. Estado de Minas, 8 mar. 1975. p. 8; NO Betânia, todos reclamam contra fábrica poluidora. Estado de Minas, 15 set. 1976. p. 5. Para avaliar a continuidade desses estabelecimentos poluidores nos anos seguintes, a despeito das açóes populares, ver: NINGUÉM sabe quantas empresas poluem. Estado de Minas, 4 mar. 1979. p. 10.

${ }^{20}$ MISÉRIA nas ruas. Estado de Minas, 14 jan. 1967. p. 4; MENDIGOS fazem o drama da cidade. Estado de Minas, 23 out. 1968. p. 16.
} 
mo modernistas por Oscar Niemayer e Burle Marx, tornou-se um local poluído por esgotos domésticos e industriais e altamente contaminado por esquistossomose. ${ }^{21}$

A especulaçáo imobiliária de residências de luxo voltou-se para áreas da zona sul da cidade, que receberam estrutura urbana adequada e prévio desalojamento de barracos e habitantes miseráveis. Desde fins dos anos 1960, lotearam-se bairros de elite, com casas elegantes, jardins e garagens, ruas com passeios adequados para arborizaçáo e regras estabelecidas de ocupação urbana: Cidade Jardim, São Bento, Mangabeiras, Belvedere. O nome do bairro Cidade Jardim indicava a exclusividade do que antes costumava ser o epíteto de toda a cidade. Mas o bairro elegante tinha episódios nada elegantes na história de sua formação: para abrir a avenida de acesso, em 1970, uma equipe do Departamento de Ordem Política e Social (Dops) — com homens armados, além de cães — "supervisionou" a derrubada de 182 barracos. A publicidade do Belvedere, situado no local mais elevado da cidade, aos pés da Serra do Curral, convidava seus proprietários a olharem a cidade de cima, longe da poluição, gozando de ar puro e do clima ameno de montanha. Novas avenidas asfaltadas abertas pela prefeitura garantiram acesso aos novos bairros. O comércio elegante da cidade se deslocou para a Savassi, também na zona sul, e logo depois — com a ascensão da violência urbana e a busca de ambientes de acesso selecionado - para o primeiro shopping da cidade, inaugurado em 1979, no bairro Belvedere. ${ }^{22}$

É certo que o desconforto trazido pela degradação urbana dependia de variaçóes espaciais, e alguns tiveram condiçôes financeiras para evitá-la, mudando-se para áreas mais nobres. Mas proponho que moradores antigos de diferentes condiçôes sociais partilhavam as dimensôes temporais implicadas no fenômeno de crescimento desordenado. Sentidos atribuídos ao passado, presente e futuro eram repletos de sentimentos paradoxais, como saudosismo diante do passado, euforia e mal-estar pelo presente, otimismo e ansiedade em relação ao futuro.

O passado pouco distante, de duas ou três décadas, era relembrado com sentimentos de perdas. As árvores dia a dia eram eliminadas nos mais variados pontos da cidade. Os jardins substituídos por estacionamento de carros. Ar puro, clima ameno, água potável e silêncio

\footnotetext{
${ }^{21}$ Sobre a degradação da Pampulha, ver: CASALARDE, Flávio. Pampulha. Belo Horizonte: Conceito, 2007. p. 64-80; GARCIA, Luiz Henrique Assis. Ruptura e expansão: Pampulha em contrastes. In: PIMENTEL, Thais (Org.). Pampulha múltipla. Belo Horizonte: MHAB, 2007. p. 89-111; GOVERNO DO ESTADO DE MINAS GERAIS. Situação ambiental na Região Metropolitana de Belo Horizonte, op. cit. p. 101; DEODATO, Alberto. A Pampulha e o prefeito. Estado de Minas, 15 abr. 1967. Caderno 3, p. 1.

${ }^{22}$ ARREGUY, Cintia; RIBEIRO, Rafael Rajão (Org.). História de bairros de Belo Horizonte: regional centro-sul. Belo Horizonte: APCBH, 2008. p. 29-35; sobre a derrubada da favela no que seria a av. Prudente de Morais, na Cidade Jardim: FAVELA acaba sob vigilância. Estado de Minas, 13 mar. 1970. p. 13; DÊ um passo à frente e vá viver no Belvedere. Estado de Minas, 4 fev. 1973. Pequenos Anúncios, p. 1. Sobre os signos de distinção e status que passaram a reger a arquitetura das casas de classes médias altas no Brasil nos anos 1950-1960 em diante, instituindo uma nova "cultura de morar", com destaque para projetos paisagísticos de jardins, ver PINTO Junior, Rafael. Casas de sonho. Tese (doutorado em história) — Programa de Pós-Graduação em História, Universidade Federal de Goiás, Goiânia, 2011. p. 98-164.
} 
escasseavam. Essa saudade foi murmurada nos versos de Drummond, que evocaram um "passado cor-de-cores fantásticas", a Belo Horizonte "provinciana saudável, de carnes leves pesseguíneas (...) lugar muito especial pela graça do clima”, remanso que seus habitantes gozavam "macio-amesendados na calma e na verde brisa irônica". ${ }^{23}$

A despeito das críticas, os apelos desenvolvimentistas conquistavam adeptos: o país crescia vertiginosamente, as classes médias compravam carros e casas, seus filhos alcançavam a universidade, o Brasil ganhou a Copa do Mundo de 1970. O país vivia o paradoxo do "carro zero e pau de arara", ${ }^{24}$ assim como do apoio de muitos ao regime, simultâneo à resistência, luta/discordância ou simples insatisfação de tantos outros.

A participação do Brasil na Conferência de Estocolmo, em 1972, foi bastante expressiva no que se refere a esses paradoxos. Perante a pressão internacional pela conservação, representantes brasileiros afirmaram que o Brasil não poderia reduzir seu crescimento industrial para compensar pecados ambientais cometidos no passado por países já desenvolvidos, apontando a pobreza como a pior poluiçấo e afirmando o direito do Brasil ao desenvolvimento econômico. Internamente, essa postura gerou sentimentos diversos. De um lado, houve comemoraçóes ufanistas do destaque brasileiro na defesa do crescimento econômico, louvada por muitos como atitude patriótica e corajosa. De outro, a situação ambiental era táo visivelmente grave que gerou ansiedades - especialmente entre a comunidade científica - pela sensação de que as autoridades manteriam seu projeto de progresso "a qualquer preço". Esse foi o caso do engenheiro sanitário Honório Botelho, da UFMG, presente na Conferência, que criticou com argumentos econômicos o desprezo da poluição em nome do desenvolvimento. Argumentava que seria "muito mais barato desenvolver um complexo industrial puro desde o início, do que ter que purificá-lo mais tarde”. ${ }^{25}$ A questão da degradação ambiental ganhou espaço na mídia, açôes populares e seminários científicos, tornando-se um tema significativo de opinião pública.

A proposta de combater a pobreza por meio do desenvolvimento para depois preocupar-se com o meio ambiente afinava-se, na verdade, ao princípio maior da política econômica do governo. No mesmo período em que o Brasil apresentava índices excelentes de crescimento

\footnotetext{
${ }^{23}$ DRUMMOND, Carlos Drummond de. Triste horizonte, op. cit.

${ }^{24}$ ALMEIDA, Maria H. Tavares; WEIS, Luiz. Carro zero e pau de arara: o cotidiano de oposição de classe média ao regime militar. In: SCHWARCZ, Lilia (Org.). História da vida privada no Brasil: contrastes da intimidade contemporânea. São Paulo: Companhia das Letras, 1998. p. 319-410.

${ }^{25}$ BOTELHO, Honório P. Poluição ambiental. Belo Horizonte: UFMG, 1973. p. 4-5. Manuscrito. (Setor de Obras Raras, Biblioteca EEUFMG, 628(063)B748p). O professor comenta ainda matéria publicada sobre o depósito de lixo a céu aberto em Belo Horizonte no jornal norueguês Dagbladet, qualificado como o mais baixo grau de miséria. Ver ainda: LAGO, André Aranha. Estocolmo, Rio, Joanesburgo. Brasília: Instituto Rio Branco; Funag, 2006. p. 115-144. Sobre a repercussão ufanista, ver: POLUIÇÃO no vizinho (editorial). Jornal do Brasil, 25 fev. 1972. p. 6; COSTA Cavalcanti reafirma que defenderá na Suécia o direito ao desenvolvimento. Jornal do Brasil, 31 maio 1972. p. 4; SANTAYANA, Mauro. Brasil pede luta contra poluição da pobreza. Jornal do Brasil, 7 jun. 1972. p. 8. Sobre opinião pública, ver GOVERNO DO ESTADO DE MINAS GERAIS. Situação ambiental na Região Metropolitana de Belo Horizonte, op. cit. p. 157-158.
} 
do PIB, a classe trabalhadora vivia o "arrocho salarial". O ministro Delfim Netto defendeu a necessidade de "deixar o bolo crescer, para depois reparti-lo". Ao fim do Milagre Econômico, sobraram índices vergonhosos de qualidade de vida humana. Em Belo Horizonte, em 1970, o índice de mortalidade infantil era de 107,7 óbitos de crianças de até um ano por mil nascidas vivas. Em 1973, esse dado havia subido para 124,8. ${ }^{26}$

Nesse contexto, sentimentos quanto ao futuro eram também paradoxais. Certamente havia euforia: grande parte dos brasileiros acreditou que o país subiria em breve ao rol do Primeiro Mundo, e alguns idosos lamentavam "não ter condiçóes biológicas para viver até o próximo milênio, quando o Brasil se equipararia ao Japão". ${ }^{27}$ Mas os dados estatísticos também causavam vertigens naqueles que pensassem no futuro próximo. $\mathrm{O}$ aumento galopante da população (figura 6) e do número de automóveis, bem como a expansão desordenada das periferias ${ }^{28} \mathrm{e}$ a rápida deterioração ambiental influenciavam prognósticos sombrios para quem assistia ao agravamento da situação, especialmente quando contrastado à postura do governo brasileiro em Estocolmo.

Figura 6

Taxas geométricas de crescimento demográfico no município de Belo Horizonte e na Região Metropolitana (RMBH)

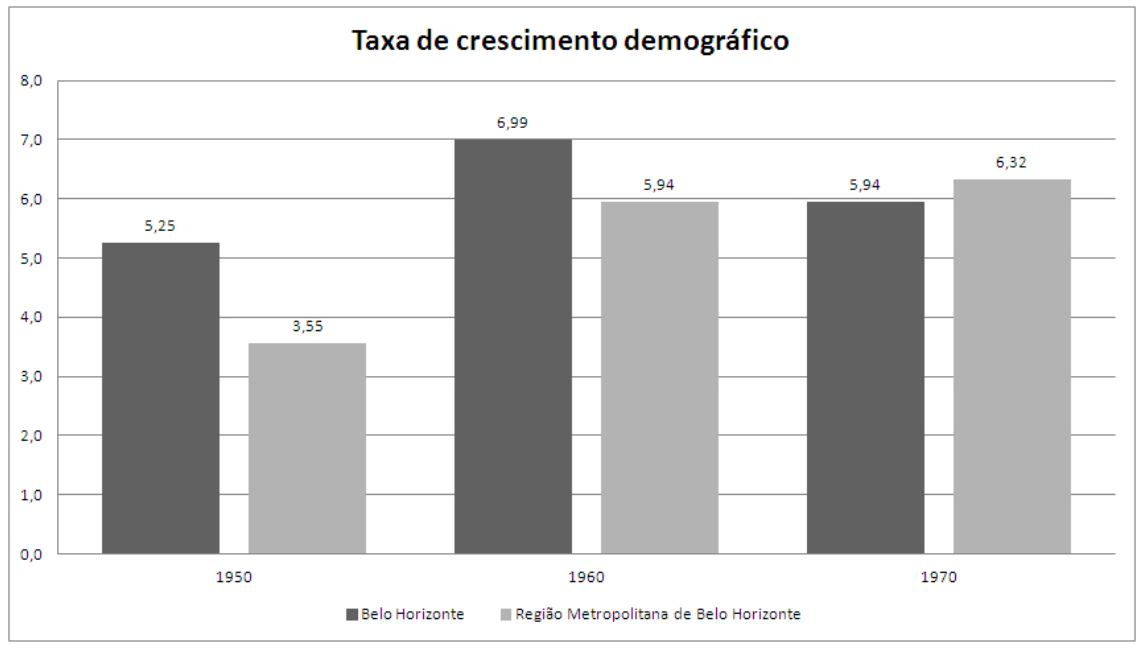

Fonte: IBGE. Elaboração: Regina Horta Duarte.

Note-se que a diminuição da taxa em BH nos anos 1970 é simultânea ao aumento nos municípios vizinhos, expressão da saturação do centro urbano e da ocupação imobiliária desordenada nas periferias.

${ }^{26}$ WOOD, Charles. Infant mortality trends and capitalist development in Brazil: the case of São Paulo and Belo Horizonte. Latin American Perspectives, v. 4, n. 56, p. 56-65, 1977.

${ }^{27}$ Como descrevem FAUSTO, Bóris. História do Brasil. São Paulo: Edusp, 2004. p. 485; e MELLO, João Manuel C.; NOVAIS, Fernando. Capitalismo tardio e sociabilidade moderna, op. cit. p. 560.

${ }^{28}$ MARQUES, Robson. Região de Belo Horizonte e a urbanização: notas sobre uma dinâmica imobiliária. In: MEDEIROS, Regina (Org.). Permanências e mudanças em BH. Belo Horizonte: Autêntica, 2001. p. 113-137. 
Interpretaçôes de tons neomalthusianos ganharam destaque. A expectativa de crescimento demográfico apostava na manutenção dos níveis de crescimento. Em 1967, quando o município de Belo Horizonte possuía 1.081.000 habitantes, o IBGE fazia estimativas extraoficiais de que a capital teria 10.464 .000 no ano 2000. Em 1973, estudos acadêmicos consideravam a mesma projeção para a virada do milênio. O mesmo pressuposto baseava as projeçôes do número de veículos. Em 1973, a prefeitura previa um milhão de veículos na capital em 1990. Um ano depois, o Departamento de Estradas e Rodagens estimou que 350 mil carros transitariam na capital em 1980. A poluição crescente trazia grandes preocupaçóes, com a expectativa de uma cidade de surdos em 2000, ou de que a saúde de muitos sucumbiria antes que as indústrias controlassem seus resíduos tóxicos. Numa charge publicada em 1975, dois cidadáos conversavam num banco de praça com espessa nuvem de fumaça ao fundo. Um deles lia no jornal que a siderúrgica Mannesmann prometia filtros nas chaminés até 1977. O outro, com ar incrédulo, de braços cruzados, mirando a fuligem, dizia: "Quem viver, verá!..... ${ }^{29}$

Assim, cientistas, formadores de opiniáo e técnicos vislumbravam um futuro próximo com problemas de dimensóes gravíssimas, o que certamente aumentou a ansiedade gerada pelo crescimento urbano em muitos habitantes da capital naqueles anos. O horizonte das expectativas de qualidade de vida urbana era desanimador. Quantos não se identificaram com os versos da canção Casa no campo? Quantos puderam realizar esse sonho, e como isso ocorreu?

\section{Verde total}

"Estamos loteando a felicidade, reserve um pedaço prá Você." Esses dizeres, parte da campanha publicitária de um dos muitos condomínios lançados em Belo Horizonte, captavam bem o sentimento de muitos citadinos entre as décadas de 1960 e 1970: a perda de uma parte da felicidade em prol do progresso e do desenvolvimento. Além de lotes, paisagens verdes, silêncio e águas cristalinas, os incorporadores negociavam a expectativa irreal de um lugar em que o tempo decorrido e as conquistas tecnológicas estariam presentes (e tudo o que isso significava: água, luz, eletrodomésticos, telefone, acesso por automóvel), mas

\footnotetext{
${ }^{29}$ WALDEMAR, José. População dobra cada dez anos e a metrópole abrange cidades vizinhas. Estado de Minas, 10 mar. 1967. p. 10; QUICK, Thelmo; PAULINI, Ernest. Contribuição ao estudo da poluição atmosférica e das doenças pulmonares em Belo Horizonte, op. cit. p. 10; PLAMBEL. Poluição atmosférica na Região Metropolitana de Belo Horizonte, op. cit. p. 6; EM BH os carros aumentam mais que a população. Estado de Minas, 28 nov. 1974. p. 13. A taxa de crescimento demográfico, entretanto, foi reduzida: em 2000, o município de Belo Horizonte tinha 2.238.526 habitantes. A crise econômica desacelerou também o crescimento no número de veículos: apenas em 2001 a capital alcançou a marca dos 706.480 veículos. Disponível em: $<$ http://portalpbh.pbh.gov.br/pbh/> (ver Estatísticas e indicadores). Acesso em: 7 fev. 2014. A charge referida é de ESTEVES, Oldack. Imagens do dia (charge). Estado de Minas, 8 ago. 1975. p. 4.
} 
a vertigem do futuro se acalmasse, mesmo que somente nos finais de semana... A mesma publicidade prometia o controle do futuro, pois o condomínio à venda se localizava "numa regiāo onde a natureza jamais será violentada por qualquer tipo de poluiçáo" (grifo meu). ${ }^{30}$ Dessa forma, a perspectiva de viver no condomínio tentava resolver o paradoxo de pessoas de melhor condição social beneficiadas pelo desenvolvimento em curso no país, cujo poder de consumo aumentara incrivelmente em decorrência do alto crescimento econômico, mas que se ressentiam da galopante deterioração ambiental do centro urbano. No condomínio, teriam o conforto da cidade, a proximidade dos serviços viabilizada pelo automóvel e a tranquilidade de habitar lugares mais preservados. A promessa de felicidade garantida (tema presente na maioria dos anúncios de condomínios) mobilizava fantasias monádicas, em que se viveria num ambiente paradisíaco, a salvo do tempo, da morte, da falta, da finitude humana, num retorno a um estágio primário de satisfação total, enfim. ${ }^{31}$

Condomínios horizontais existiam em Belo Horizonte desde fins dos anos 1950, quando foram inaugurados o Retiro das Pedras (1957), o Morro do Chapéu e o Estância Serrana (ambos em 1958), todos na regiáo sul da cidade. O Estância Serrana teve a peculiaridade de ser organizado pela Mannesmann, que ali situou as famílias dos altos funcionários alemáes que vinham trabalhar em Belo Horizonte, numa comunidade bastante fechada, logo apelidada de "Morro do Chucrute". Retiro das Pedras e Morro do Chapéu foram lançados em áreas de paisagens privilegiadas, e suas sedes sociais tornaram-se locais de festas elegantes e disputadas pela alta sociedade. O sucesso desses dois últimos no fim dos anos 1950 deveu-se, em parte, à atribuição de um "ambiente europeu" e sofisticado aos clubes, localizados em áreas montanhosas e de clima ameno, assim como ao prazer de sair de carro nos fins de semana, num momento de ascensão da "cultura do carro" embalada pelos anos dourados, expressão de euforia e de aventura. O campo de golfe do Morro do Chapéu coroava o desejo de sofisticação de elites em ascensão e oferecia opçóes de lazer para os executivos de empresas estrangeiras e para membros de corpos consulares. ${ }^{32}$

${ }^{30}$ ESTAMOS loteando a felicidade. Estado de Minas, 13 nov. 1975. Pequenos Anúncios, p. 3. Ver também: COSTA, Heloisa. Mercado imobiliário, Estado e natureza na produçáo do espaço metropolitano. In: COSTA, Heloisa et al. (Org.). Novas periferias metropolitanas. Belo Horizonte: C/A, 2006. p. 101-124; PIRES, Claudia. Evolução do processo de ocupação urbana do município de Nova Lima. Dissertação (mestrado em geografia) - Programa de Pós-Graduação em Geografia, Universidade Federal de Minas Gerais, Belo Horizonte, 2003.

${ }^{31}$ Sugiro aqui as possibilidades da leitura psicanalítica do sonho do verde total. Meu argumento de mal-estar dos belorizontinos apoia-se em FREUD, Sigmund. O mal estar da civilizaçâo. São Paulo: Companhia das Letras, 2010. Sobre possibilidades de interpretação psicanalítica de processos históricos, ver: CASTORIADIS, Cornelius. Psicanálise e sociedade I e II. In: CASTORIADIS, Cornelius. As encruzilhadas do labirinto: os domínios do homem. Rio de Janeiro: Paz e Terra, 1987. p. 39-53, 95-107.

${ }^{32}$ DUARTE, Regina Horta. It does not even seem that we are in Brazil: country clubs and gated communities in Belo Horizonte, Brazil, 1951-1964. J. Lat. Amer. Stud., Cambridge, v. 44, n. 3, p. 435-466, 2012. Sobre o Estância Serrana: HEEP, Hans. Entrevista. Estância Serrana, 30 nov. 2013. Há um paralelo com a cultura norte-americana, em que "to go riding" nos finais de semana se tornou uma experiência familiar prazerosa nos anos 1950. JACKSON, Kenneth. Grabgrass frontier. Nova York: Oxford University Press, 1985. p. 181. 
Os lançamentos, nos anos 1970, ganharam novos sentidos. Os empreendimentos não se constituíram em torno de clubes: alguns até prometiam a construçáo de áreas sociais e esportivas, mas elas não se concretizaram. Muitas casas continuaram ocupadas apenas nos finais de semana, mas, pouco a pouco, algumas famílias decidiram se estabelecer ali, construindo um estilo inédito de vida. Os condomínios mais sofisticados situaram-se ao sul da cidade, a quinze ou vinte minutos de carro da praça Savassi, próximos aos bairros mais elegantes e às melhores escolas particulares. Se o trânsito no centro da cidade era caótico, as vias percorridas entre os condomínios e a zona sul eram tranquilas e o fluxo era rápido e previsível. $^{33}$

Em face da decadência do centro como área desejável para habitar e dos valores altos dos lotes nos bairros sofisticados na zona sul, no perímetro do município, os preços de lotes em condomínios eram convidativos para muitas pessoas que, dessa forma, podiam direcionar o investimento maior à construçáo da casa e dos jardins, em terrenos de 2 mil metros quadrados ou mais. Para jovens profissionais liberais, professores universitários ou funcionários qualificados de órgáos públicos, essa opção atendia às expectativas tanto de bem-estar quanto de distinção social, já que os condomínios garantiam vizinhança seleta e - não menos importante - "cabiam no bolso". A possibilidade de financiamento pelo Banco Nacional da Habitação (BNH) facilitava tudo. Criado em 1964 para estimular a construção civil por meio do setor de casas populares, o sistema direcionou investimentos, a partir de 1970, para o mercado médio (classes média e alta). Uma propaganda da Caixa Econômica Federal de 1975 é esclarecedora. Na foto, com o título "Natureza morta", um menino olha a metrópole através da janela com grades. $\mathrm{O}$ texto faz consideraçôes sobre o caráter implacável do progresso e a vida de crianças presas em apartamentos: todo dia a natureza era destruída, e "até que todos tomassem consciência disso, talvez fosse tarde demais". Ninguém era contra o desenvolvimento, mas, "e o cheiro de mato?". ${ }^{44}$

A escolha de morar nos condomínios pode ser vista como uma saída individual de pessoas que assistiam a um panorama desanimador na cidade. Havia, certamente, mudanças em curso. As açóes populares contra poluidores na Regiáo Metropolitana de Belo Horizonte foram importantes: a ação contra a fábrica de Cimento Itaú, em 1975, configurou-se como um verdadeiro marco nas iniciativas de combate à poluição atmosférica, num conflito que envolveu sociedade civil, imprensa, autoridades locais e presidência da República. No âmbito estadual e federal, ocorriam os primeiros seminários sobre o tema, a comunidade cientí-

${ }^{33}$ UCHOA, Maria Angela. Entrevista. Condomínio Vila del Rey, 21 nov. 2013; ANDRADE, Marlene Vieira Chaves de. Entrevista. Condomínio Estância Serrana, 12 dez. 2013.

${ }^{34}$ CAIXA ECONÔMICA FEDERAL. Natureza morta. Estado de Minas, 28 ago. 1975. p. 9; AZEVEDO, Sérgio. Vinte e dois anos de política de habitação popular. Revista Administraçáo Pública, v. 22, n. 4, p. 107-119, 1988. Sobre financiamento de casas de condomínios horizontais pelo BNH: SANTOS, Regina. Rochdale e Alphaville. Tese (doutorado em geografia) - Programa de Pós-Graduaçáo em Geografia, Universidade de São Paulo, São Paulo, 1994. p. 201-206. 
fica se pronunciava e encaminhava propostas, as primeiras leis eram decretadas. Destaca-se, principalmente, a criaçáo da Secretaria Especial do Meio Ambiente (Sema), em 1973, ocupada pelo cientista Paulo Nogueira Neto, fruto certamente da dupla pressão internacional e da opinião pública interna, após a controversa posição do Brasil na Conferência de Estocolmo. ${ }^{35}$ Mas essas açóes tinham resultados lentos, e mesmo que alguns as acompanhassem com esperança, mudanças efetivas não eram esperadas a curto prazo.

Se a questấo ambiental ganhava espaço na mídia e no discurso de cientistas brasileiros, náo era experimentada efetivamente como questáo política. Os discursos da direita privilegiavam o desenvolvimento e o combate à "poluiçẫo da pobreza", refugiando-se no elogio ufanista da natureza do Brasil. Para a esquerda, proteger a natureza parecia algo distante, "pequeno-burguês", quase ridículo diante das grandes urgências revolucionárias. ${ }^{36}$ Nessas condiçôes, ansiedades sobre a destruição ambiental foram predominantemente vividas no Brasil daqueles anos como sentimento individual e extemporâneo.

As motivaçóes apontadas por moradores nos anos 1970 para sua escolha são diversas. A ex-moradora do centro se entristecia pelos mendigos à sua porta, além de se incomodar com a fumaça preta dos ônibus que atingia o carrinho de seu bebê sempre que ia ao Parque Municipal. O médico recém-chegado de especialização em Paris não conseguia estudar com o barulho dos automóveis. O jovem pesquisador norte-americano que veio morar no Brasil viu no condomínio algo mais próximo dos subúrbios de seu país natal, ao mesmo tempo que se surpreendeu com a degradação da cidade. O maestro tinha o prazer de receber jovens músicos para ensaios diante de uma ampla visão da esplêndida mata do Jambreiro. $\mathrm{O}$

\footnotetext{
${ }^{35}$ Sobre a Itaú: GUIMARÃES FILHO, Tito. A Fumaça assassina. Belo Horizonte: Armazém de Ideias, 2000. Alguns estudos técnicos e anais de eventos da época encontram-se em: INSTITUTO DE PLANEJAMENTO ECONÔMICO E SOCIAL. Poluição Industrial no Brasil. Brasília: Ipea/Iplan, 1975; CÂMARA DOS DEPUTADOS. Anais do I Simpósio de Poluição Ambiental. Brasília: CDI, 1975. 5 v.; GOVERNO DO ESTADO DE MINAS GERAIS. Situação ambiental na Região Metropolitana de Belo Horizonte, op. cit.; NOGUEIRA NETO, Paulo. Política governamental de controle da poluição. In: PAULINI, Ernest; TOMAGNINI, B. Controle da poluição das indústrias: Simpósio de Engenharia Química. Belo Horizonte: Grêmio da EEUFMG, 1978, Mimeografado. (Biblioteca EEUFMG, Manuscritos, Ref: 628.5(063) C764.1978). A Sema foi criada pelo Decreto 73.030, de 30 de outubro de 1973. Ver ainda FREITAS, José Rabelo. Entrevista (Ambientalistas Mineiros). Belo Horizonte: Programa de História Oral/CEM/UFMG, 2006; FERRAZ, Sarah. Triste horizonte: movimentos em defesa da Serra do Curral. Trabalho de Conclusão (bacharelado em história) - Departamento de História, Universidade Federal de Minas Gerais, Belo Horizonte, 2008.

${ }^{36}$ RICAS, Maria Dalce. Entrevista (Ambientalistas mineiros). Belo Horizonte: Programa de História Oral/ CEM/UFMG, 2007. É certo que havia matizes entre as posturas políticas, mas naqueles anos a oposição entre esquerda e direita se aprofundou. Não obstante essa polarização, Heloisa Starling generosamente me alertou sobre a dissonância dos movimentos de contracultura, no seio dos quais anticonsumismo, pacifismo, vegetarianismo, macrobiótica e vida comunitária se sintonizavam com o movimento hippie mundial, sensíveis às questóes ambientais. Em Minas Gerais, o Festival de Inverno, realizado pela UFMG em Ouro Preto, a partir de 1969, tornou-se um evento decisivo para a experimentaçáo cultural alternativa. STARLING, Heloisa. Coisas que ficaram muito tempo por dizer. In: MALINA, Judith. Diário de Judith Malina, o Living Theatre em Minas Gerais. Belo Horizonte: Arquivo Público Mineiro, 2008. p. 15-37, especialmente p. 29-33.
} 
incorporador quedava-se estupefato à noite, com o céu límpido, a ponto de decidir nomear todas as ruas de seu empreendimento, para onde se mudou, com nomes de constelaçóes. O pesquisador e professor universitário apaixonou-se pela paisagem do Retiro, que exercia verdadeiro magnetismo sobre quem o visitava pois, ali, "para olhar o céu não olhe para cima, olhe para frente". ${ }^{37}$

Os nomes dos condomínios mobilizavam desejos e fantasias de refúgio e verde, além da imagem recorrente da "vila", em contraposição à metrópole: Retiro das Pedras, Ville de Montagne, Vila del Rey, Estância Serrana, Vila Campestre, Vila Verde e Jardins de Petrópolis, entre outros. As ruas curvilíneas, em contraste com o traçado quadriculado do centro de Belo Horizonte, obrigavam à diminuição da velocidade do automóvel para a contemplação dos arredores. A nomeaçáo aludia aos signos do mundo natural. Para as alamedas, referências astrais (do Universo, Centauro, Cruzeiro do Sul, Aldebarã) e botânicas (Pinheiros, Paineiras, Ipês, Palmeiras, Sibipirunas). Ruas de passarinhos: do Colibri, Bem-te-vi, Juriti, Cardeal, Andorinha. Outros nomes remetiam à fortuna dos moradores: Alameda da Liberdade, do Paraíso, dos Sonhos, do Sorriso. Havia também referências a serras brasileiras: Mantiqueira, da Canastra, dos Órgãos, do Mar. Palavras inscritas nas placas remetiam aos elementos da flora e fauna, estrelas, serras, sensaçôes, aspiraçóes e gestos, na clara intenção de conferir lirismo ao território a ser habitado e investido de significados. ${ }^{38}$

No material publicitário, alguns anúncios mobilizavam o desejo de um estilo de vida europeu. O Retiro das Pedras era uma "escandalosa imitação do clima e da paisagem suíça", a 1.450 metros de altitude. Outras chamadas agenciavam aspiraçôes à qualidade de vida: "venha morar onde a vida vale a pena", e a foto mostrava uma família caminhando numa belíssima trilha. Em outra imagem, a página de um livro estampava uma foto da cidade, concreto e edifícios. A página seguinte se deixava entrever, pois a primeira estava sendo virada. Em baixo, a chamada: "troque o ar que você respira por um clima de montanhas". No Ville de Montagne, "trânsito, só o dos pássaros". Lotes financiados ofereciam "em nome dos pais e dos filhos (...) um lugar ao sol, enquanto é tempo". Duas portarias garantiriam a "liberdade sem medo". A rejeiçấo ao afastamento era combatida pela veiculação de pequenos mapas, com indicaçôes da posição do condomínio em relação à Praça Savassi, a distância em quilômetros e o tempo estimado de dez, quinze, vinte minutos para acessar os "últimos terrenos de natureza na zona sul”, pois "a porção nobre de Belo Horizonte só tem um caminho para crescer, a zona sul”. Anúncio do Ouro Velho Mansóes, lançado em 1969 — "para quem sabe gozar a vida" numa "paisagem europeia dentro da cidade" —, recorria à sinestesia,

${ }^{37}$ ANDRADE, Entrevista; COSTA, Paulo. Entrevista. Vila del Rey. 21 nov. 2013; LIBBY, Douglas. Entrevista. Vila del Rey, 11 nov. 2013; RIBEIRO, Antonio. Entrevista. Belo Horizonte, 12 fev. 2014; COSTA, Carlos. Entrevista. Ville de Montagne, 5 nov. 2013; CANFORA, Hugo. Entrevista. Belo Horizonte, 19 dez. 2013.

${ }^{38}$ Sobre a "aventura das palavras" da cidade, ver BRESCIANI, Maria Stella (Org.). Palavras da cidade. Porto Alegre: EUFRGS; Unesco, 2001. p. 9-16; DEPAULE, Jean-Charles; TOPALOV, Christian. A cidade através de suas palavras. In: BRESCIANI, Maria Stella (Org.). Palavras da cidade, op. cit. p. 17-38. 
apresentando o local "onde você vai respirar a beleza do ar puro". ${ }^{39}$ O Vale do Ouro, "verde total" a noroeste da cidade, ilustrava o contraponto entre a cidade vertical e com chaminés industriais com o condomínio-paraíso arborizado acessível pela estrada (figuras 7, 8 e 9).

\section{Figura 7}

Ouro Velho Mansões

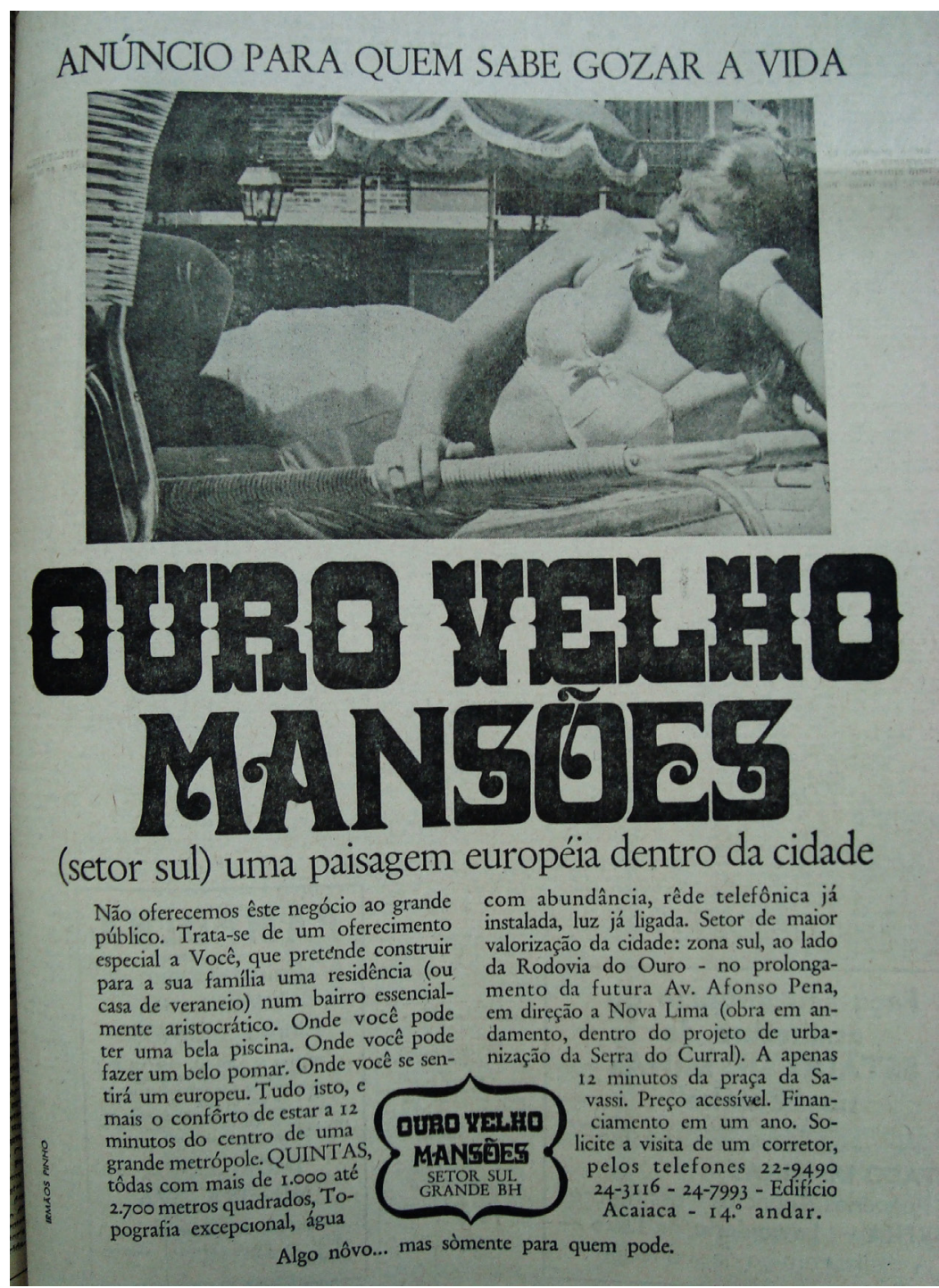

Fonte: Estado de Minas, 21 dez. 1969. 4º caderno, p. 3 (Hemeroteca Histórica de Minas Gerais).

\footnotetext{
${ }^{39}$ RETIRO. Estado de Minas. 13 jan. 1974. Pequenos Anúncios, p. 3; TROQUE o ar que você respira. Estado de Minas, 10 out. 1976. Pequenos Anúncios, p. 1; PLANTE-SE. Estado de Minas, 5 set. 1976. Pequenos Anúncios, p. 1; PARA quem sabe gozar a vida. Estado de Minas, 21 dez. 1969. Caderno 4, p. 3; O VERDE total. Estado de Minas, 20 ago. 1972. Pequenos Anúncios, p. 1.
} 
Figura 8

Vale do Ouro

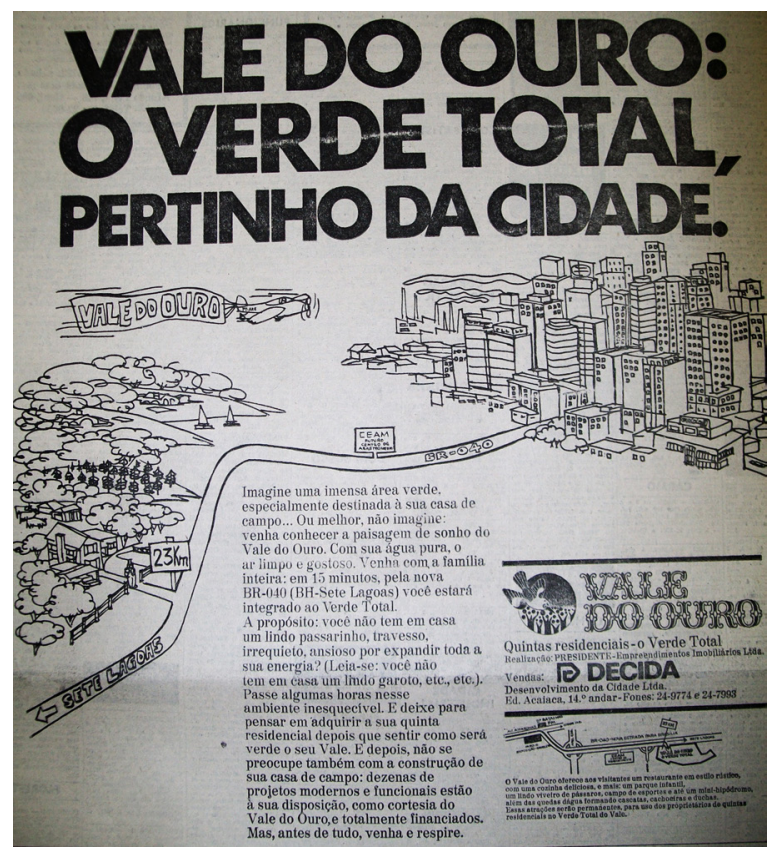

Fonte: Estado de Minas, 20 ago. 1972. Pequenos Anúncios, p. 1 (Hemeroteca Histórica de Minas Gerais).

\section{Figura 9}

Ville de Montagne

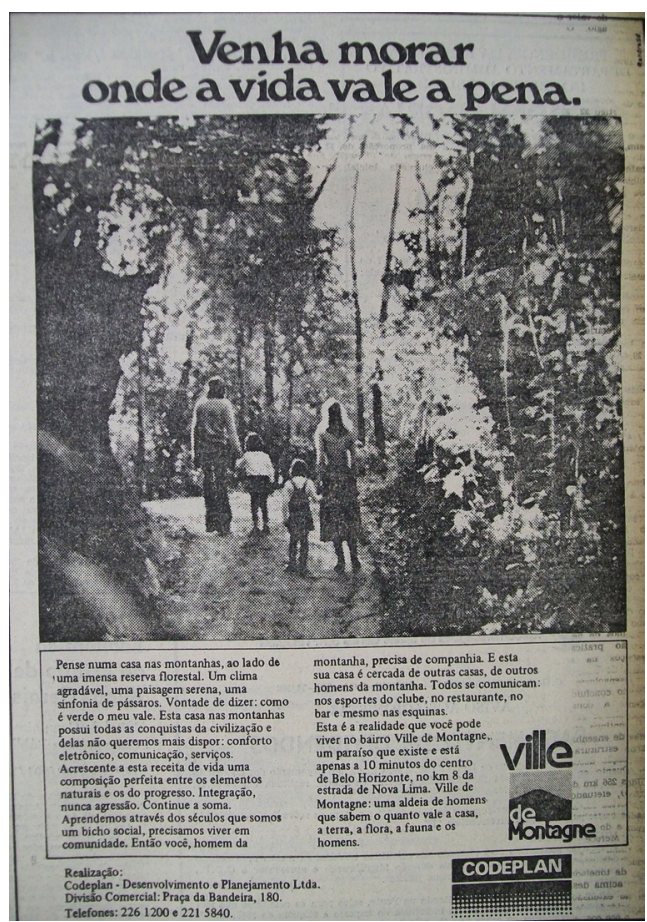

Fonte: Estado de Minas, 19 jun. 1976. p. 7 (Hemeroteca Histórica de Minas Gerais). 
Apesar de ser uma decisáo individual das famílias, a escolha da mudança para um condomínio horizontal implicou uma convivência comunitária. A despeito das promessas mirabolantes dos anúncios, moradores recém-chegados tiveram, na grande maioria dos casos, de se organizar não só para obter instalaçôes de água e fossas adequadas, mas também para estabelecer regras de convivência e construção, ou mesmo o almoço de domingo em conjunto. Esforços contínuos de arborização tornaram a área dos condomínios muito mais preservada, como mostram fotos particulares guardadas por antigos moradores. ${ }^{40}$

Ao longo das décadas, esses primeiros proprietários se ressentiram muito da chegada de novos habitantes e da expansão de novos empreendimentos que ameaçam suas paisagens verdes. Muitos condomínios tiveram uma valorização surpreendente, nos últimos anos, e têm sido procurados por pessoas de nível econômico bastante alto, o que tem alterado a arquitetura e o perfil do local, para desconforto dos mais antigos, levando à organização de iniciativas preservacionistas. O problema, entretanto, é quase tão antigo como os condomínios: em 1970, a primeira ação popular foi movida por um jovem advogado, primeiro brasileiro a se mudar para o Estância Serrana, até então habitada apenas por alemães. Ao ver todo o seu esforço de construir sua casa num lugar aprazível ser ameaçado pela especulação imobiliária iminente e o loteamento excessivo, entrou na justiça, alegando que a ocupação da área não podia contemplar apenas o direito de propriedade, mas também sua função coletiva e social. O processo se arrastou por décadas, e nesse tempo o Estância tornou-se um dos condomínios de maior área preservada nas imediaçôes de Belo Horizonte. ${ }^{41}$ Essa e outras ações, para as quais o espaço deste artigo é pequeno, mostram que a vida nos condomínios foi também constituinte de práticas ambientalistas nos anos que se seguiram.

\section{Conclusóes}

A criação dos condomínios horizontais privados como opção de moradia esteve diretamente relacionada às condiçóes históricas que acarretaram a deterioração e abandono do centro urbano de Belo Horizonte. Nesse contexto, alguns tiveram o privilégio de poder esco-

${ }^{40}$ COSTA, Paulo. Entrevista, op. cit.; UCHOA, Maria Angela. Entrevista, op. cit.; CANFORA, Hugo. Entrevista, op. cit.; BRANDÁO, Pedro. Sociabilidade urbana: o caso do condomínio Ville de Montagne. Monografia (iniciação científica) - Pontifícia Universidade Católica de Minas Gerais, Belo Horizonte, 2003; NASCIMENTO, Alexandra. Do Vila del Rei ao Alphaville. In: COSTA, Heloisa et al. (Org.). Novas periferias metropolitanas. Belo Horizonte: C/Arte, 2006. p. 339-364; ANDRADE, Luciana. Os condomínios fechados e os novos empreendimentos de cultura e lazer em Nova Lima. In: COSTA, Heloisa et al. (Org.). Novas periferias metropolitanas, op. cit. p. 275-289.

${ }^{41}$ ARAUJO, Aloizio Gonzaga de Andrade. Entrevista. Estância Serrana, 12 dez. 2013. Ver ainda LIBBY, Douglas. Entrevista, op. cit. Nos Estados Unidos, a expansão dos subúrbios foi diretamente ligada à mobilização em defesa do ambiente, como demonstra ROME, Adam. The bulldozer in the countryside. Cambridge: Cambridge University Press, 2001. 
lher o sonho da casa no campo, atraídos por promessas de uma vida renovada, mergulhados nos paradoxos do desenvolvimento e dos dramas sociais, políticos e ambientais em curso no Brasil durante a ditadura civil-militar.

A constatação da simultaneidade desses processos na capital de Minas Gerais tem possíveis paralelos com o que ocorreu em outras grandes metrópoles brasileiras, e também em outras cidades latino-americanas. Essa perda de qualidade aprofundar-se-ia gravemente nas décadas de 1980 e 1990, reforçada pela expansão de espaços segregados em detrimento de espaços de acesso público. O boom dos shopping centers é outro capítulo decisivo desse processo. Condomínios privados se tornam cada vez mais presentes não apenas no Brasil, mas também no Chile, Argentina, Peru, Costa Rica, Panamá e México, alterando o dinamismo dessas cidades latino-americanas. Tal expansão responde a demandas de isolamento social das elites e tem profundas implicações políticas. A vida nessas "ilhas" — verdadeiros universos autocentrados - esvazia espaços públicos, aprofunda o abandono das áreas centrais das urbes, desvaloriza práticas de cidadania e rejeita valores democráticos de liberdade e igualdade social.

A zona sul de Belo Horizonte, onde surgiram seus primeiros condomínios, é hoje a maior área de concentração de empreendimentos imobiliários fechados, mas eles se expandem também sobre o vetor norte. A situação atual, por sua vez, evidencia como os dramas da vida nas grandes metrópoles de forma alguma se solucionaram com o refúgio em seus arredores. Problemas de poluição, devastação e insegurança atingem mais e mais o cotidiano de seus moradores: muros altos com dispositivos elétricos, seguranças armados, ameaça das atividades de mineração ou industriais do entorno, dificuldades em destinar o lixo produzido, perigos de contaminação das nascentes e córregos, engarrafamentos nas vias de acesso ao centro urbano, conflitos entre moradores que priorizam a preservaçáo e outros interessados em modernizar os serviços do condomínio, ameaças de desmate pela fúria da especulação imobiliária. A expansão das periferias pobres no entorno dos condomínios trouxe para perto os "indesejáveis" que, paradoxalmente, são aqueles que ali trabalham como pedreiros, faxineiras, babás, jardineiros etc. Cresceu o nível econômico-social dos moradores: a especulação imobiliária elevou o preço dos terrenos e casas; equipamentos coletivos cada vez mais diversificados acarretam o aumento das tarifas mensais.

Os problemas urbanos invadiram essas áreas de pretenso refúgio, e de suas janelas os moradores observam, a cada dia, mais e mais casas construídas em seu horizonte antes tão exclusivo. A busca do verde continua relevante, mas é cada vez menos satisfatória, numa regiáo à beira de um colapso ambiental. Enfim, não existe refúgio possível: a cidade chegará. As soluçôes individuais e familiares evidenciam seus limites. A experiência comunitária de pretensas "vilas" de convívio entre iguais se desfez, evidenciando que a conquista da preservação ambiental e da qualidade de vida nas cidades é sobretudo uma questão política, com urgência de açôes que contemplem todos os cidadáos e o território comum onde habitam. 
Sociedade, ambiente e política encontram-se inextricavelmente relacionados no passado, presente e futuro das cidades. Perspectivas que abarquem o conjunto desses aspectos efetivamente contribuirão para o inesgotável esforço de decifrar os mistérios das metrópoles, essas esfinges que parecem nos devorar a cada dia, ao mesmo tempo que nos fascinam, estimulando nossa criatividade, sonhos de superação e busca da felicidade. 